\title{
ARTICLES
}

\section{THE INTERNATIONAL COURT OF JUSTICE AND THE CONCEPT OF STATE PRACTICE}

\begin{abstract}
A. MARK WEISBURD*
ABSTRACT

State practice is an important element of international law, both as a key component of customary international law and as a crucial tool for interpreting treaties. In this Article, the Author seeks to show that there are important flaws in the International Court of Justice's application of state practice. The Court has relied on actual practice to determine the content of customary rules surprisingly rarely, instead frequently basing its conclusions instead on non-binding actions by international bodies or on its own decisions. In some cases, it has reached decisions clearly inconsistent with significant and relevant state practice; in others, it has proclaimed doctrines unsupported by state behavior as rules of law. The Court has been inconsistent in its treatment of the practice of parties to treaties in cases presenting interpretation questions, sometimes proclaiming the necessity of relying on such practice while on other occasions failing even to acknowledge the existence of practice contrary to the result it reaches. This behavior by the Court is problematic for a number of reasons and, paradoxically, makes the Court itself an impediment to wider reliance on international law.
\end{abstract}

\section{INTRODUCTION}

* Martha M. Brandis Professor of Law, University of North Carolina at Chapel Hill. The Author gratefully acknowledges the support of the Carolina Law Foundation in the preparation of this Article. 
Among international lawyers, there is no dispute that determining the precise content of customary international law ("CIL") is difficult, and that treaty terms are not always easy to construe. In such circumstances, there would be obvious utility in establishing an impartial tribunal composed of experts in international law who can resolve inter-state disputes by sorting out the complexities of CIL and applying their expertise to questions of treaty interpretation. Of course, states have attempted to do just that, starting with the Permanent Court of International Justice ("PCIJ") and replacing that court with the International Court of Justice ("ICJ" or the Court) after World War II. While a number of specialized international tribunals have been created in recent decades, the ICJ remains the only international tribunal whose jurisdiction is not limited to a specific subject matter.

Assessments of the Court vary. There is, to be sure, much reason to see the ICJ as important and useful. The Charter of the United Nations declares the ICJ to be "the principal judicial organ of the United Nations." 1 The task of electing the judges of the court is seen as a matter of sufficient moment to require the participation of both the General Assembly and the Security Council of the United Nations. ${ }^{2}$ Scholarly assessment is generally favorable. For instance, according to the Third Restatement of Foreign Relations Law, "to the extent that decisions of international tribunals adjudicate questions of international law, they are persuasive evidence of what the law is. The judgments and opinions of the International Court of Justice are accorded great weight." 3 One can find similar statements in the writings of highly regarded scholars of international law. As an example, Judge Cassese has observed:

[G]iven the rudimentary character of international law, and the lack of both a central lawmaking body and a central judicial institution endowed with compulsory jurisdiction, in practice many decisions of the most authoritative courts (in particular the ICJ) are bound to have crucial importance in establishing the existence of customary rules, or in

1 U.N. Charter art. 92.

2 U.N. Charter Statute of the International Court of Justice arts. 4-12, 59 Stat. 1031, U.N.T.S. 993 [hereinafter I.C.J. Statute].

3 Restatement (THIRD) OF THE ForEIGN RELATIONS LAW OF THE UNITED STATES, $\S 103 \mathrm{cmt}$. b (1987). 
defining their scope and content, or in promoting the evolution of new concepts. ${ }^{4}$

Further, a casebook widely used in American law schools states, "the decisions of the International Court of Justice are, on the whole, regarded by international lawyers as highly persuasive authority of existing international law." 5

Despite the foregoing, it is also true that particular ICJ decisions have been strongly criticized. For example, the Court's decision in the merits phase of Military and Paramilitary Activities in and against Nicaragua (Nicar. v. U.S.) ${ }^{6}$ drew highly critical comments from several commentators; 7 its decisions in Oil Platforms (Iran $v$. United States) ${ }^{8}$ and Legal Consequences of the Construction of a Wall ${ }^{9}$ also received a fair amount of negative reaction. ${ }^{10}$ Generally,

4 ANTONIO CASSESE, INTERNATIONAL LAW 159 (2001).

5 LORI F. DAMrosch ET AL., INTERNATIONAL LAW: CASES AND MATERIALS 134-35 (4th ed. 2001).

6 Military and Paramilitary Activities (Nicar. v. U.S.), 1986 I.C.J. 14, 118-119 (June 27) (holding that the United States' unsolicited collective self-defense efforts in Nicaragua violated the customary international law established through the U.N. Charter).

7 See, e.g., Anthony D'Amato, Trashing Customary International Law, 81 AM. J. INT'L L. 101, 102 (1987) (arguing that the ICJ's reliance on the U.N. Charter rather than state practice as the source of customary international law in Nicar. v. U.S. misunderstood the purpose of customary law); Thomas M. Franck, Some Observations on the ICJ's Procedural and Substantive Innovations, 81 AM. J. INT'L L. 116, 116-120 (1987) (disagreeing with the ICJ's holding in Nicar. v. U.S. because of the court's weighting of evidence, interpretation of customary international law, and interpretation of the substantive principle of collective self-defense); John Lawrence Hargrove, The Nicaragua Judgment and the Future of the Law of Force and Self-Defense, 81 AM. J. INT'L L. 135, 137-43 (1987) (arguing that the ICJ proceeded beyond interpreting the U.N. Charter in Nicar. v. U.S. and weakened the international right of self-defense as a result).

8 Oil Platforms (Iran v. U.S.), 2003 I.C.J. 165, 196-198 (Nov. 6) (holding that the U.S. destruction of Iranian oil platforms in the Persian Gulf was not a valid use of self-defense, since it was not objectively shown that self-defense was necessary).

9 Legal Consequences of the Construction of a Wall in the Occupied Palestinian Territory (Wall Case), Advisory Opinion, 2004 I.C.J. 136, 201 (July 9) (holding that Israel's construction of a wall in the Occupied Palestinian Territory was contrary to international law).

10 For reaction to the Oil Platforms case, see William H. Taft, IV, Self-Defense and the Oil Platforms Decision, 29 YALE J. INT'L L. 295, 298-306 (2004) (arguing that the ICJ's ruling on self-defense in Oil Platforms was not only unnecessary to decide the particular dispute, but also could be read to unduly limit the right of selfdefense); Ruth Wedgwood, The ICJ Advisory Opinion on the Israeli Security Fence and the Limits of Self-Defense, 99 AM. J. INT'L L. 52, 52, 57-61 (2005) (arguing that the ICJ's holding in Oil Platforms limited the right of self-defense to situations where 
however, critics have focused on the results in individual cases, rather than on evaluating the Court's overall performance.

To understand why this lack of more general analyses of the Court is important, it is crucial to realize that the authority expressly vested in the Court is rather limited. Under its Statute, the ICJ has jurisdiction in contentious cases only when the states involved in the dispute have consented to that jurisdiction. ${ }^{11}$ Further, the Statute provides that the ICJ's decisions are binding only "between the parties and in respect of that particular case." 12 Also, no international instrument provides for the enforcement of the ICJ's judgments except Article 94 of the Charter of the United Nations, which leaves to the discretion of the Security Council the issue of whether to enforce any particular judgment. ${ }^{13}$ These provisions, taken together, make it impossible for the ICJ to control the interpretation of international law in the way, for example, that the Supreme Court of the United States can control interpretation of the Constitution. Or, more precisely, these provisions indicate the refusal of the states which established the ICJ to confer upon it a competence to make determinations of the content of

the threat was already too severe and hindered states' ability to protect civilians through action that is valid under international law as self-defense). For reaction to the Wall case, see Sean D. Murphy, Self-Defense and the Israeli Wall Advisory Opinion: An Ipse Dixit from the ICJ?, 99 AM. J. INT'L L. 62 (2005) (arguing that the ICJ's holding in the Wall Case lacked extensive factual analysis or sufficiently deep reasoning); Michla Pomerance, The ICJ's Advisory Jurisdiction and the Crumbling Wall Between the Political and the Judicial, 99 AM. J. INT'L L. 26, 32-42 (2005) (arguing that the ICJ's decision in the Wall Case was unduly influenced by political considerations).

11 This consent may be ad hoc. I.C.J. Statute, supra note 2, art. 36, para. 1. Alternatively, this consent may take the form of a provision in a treaty providing that disputes involving that treaty shall be resolved by the ICJ-an advance consent, in other words. See also Shabtai Rosenne, 2 The LAW AND PRActice of THE INTERNATIONAL COURT 1920-2005, 645-49 (4th ed. 2006) (explaining the role of compromissory clauses in bilateral and multilateral treaties). In addition, the Statute permits states to declare their consent generally to the ICJ'S compulsory jurisdiction in cases wherein the other parties have similarly consented. I.C.J. Statute, supra note 2, art. 36, para. 2. Relatively few states have accepted jurisdiction under this provision-sixty-five states currently have made declarations under Article 36, Paragraph 2, not including four of the five permanent members of the Security Council (China, France, Russia, the United States) or such important states as Brazil, South Africa, or Venezuela. International Court of Justice, Declarations Recognizing the Jurisdiction of the Court as Compulsory, http://www.icj-cij.org/jurisdiction/index.php?p1=5 \&p2=1\&p3=3 (last visited Dec. 3, 2009).

12 I.C.J. Statute, supra note 2, art. 59.

13 U.N. Charter, art. 94. 
international law which, as a practical matter, can be made binding on the world.

In these circumstances, the Court's ability to resolve individual disputes and its capacity to clarify the content of international law depend on states' willingness to bring cases to it, which in part depends on the perceived quality of its work. Even if it lacks the authority to make generally binding legal determinations, states can and presumably will accept its view of the law if they perceive the Court as an institution upon which they can rely for a careful resolution of legal questions. Similar considerations, one would hope, would apply to scholars seeking to determine whether the Court is a reliable expositor of international law. In this connection, a distinction drawn by Professor Movsesian is helpful. He distinguishes between judicial decisions having what he calls "disposition value" - decisions which lower courts are obliged to accept as stating the law because of the place of the deciding court in the relevant judicial hierarchy-and decisions having "information value" - decisions which another court is not legally obliged to follow, but which are nonetheless influential because of the expertise of the court and the quality of its analysis. ${ }^{14}$ Thus, the ICJ's expertise in matters of international law could be so great as to make its opinions influential with national courts, governments, and scholars, regardless of their formally binding character. On the other hand, if analysis gives reason to question the quality of the Court's work, states will be on notice of the risks of taking cases to the Court, and scholars will learn to treat its opinions with caution.

This Article attempts such an analysis of one aspect of the Court's jurisprudence: its treatment of state practice. The significance of state practice in international law is difficult to overstate. It is accepted as a component of CIL. ${ }^{15}$ Furthermore, the practice of states' parties to a particular treaty is understood to be an important element in determining the treaty's meaning. ${ }^{16}$

14 See Mark L. Movsesian, Judging International Judgments, 48 VA. J. INT'L L. 65, 88-89 (2007) (describing the domestic effects of international judgments in countries that utilize a "dualist" approach).

15 I.C.J. Statute, supra note 2 , art. 38.

16 Vienna Convention on the Law of Treaties, art. 31, para. 3(b), May 23, 1969, 1155 U.N.T.S. 331 [hereinafter Treaties Convention]. 
Indeed, the Court itself has stated that the use of parties' practice to interpret treaties is an element of CIL. ${ }^{17}$

In light of the significance of state practice, the ICJ's approach to determining its content and relevance can shed considerable light on the Court's actual performance of its task. Accordingly this Article will, in the next Section, discuss twenty-seven cases decided by the ICJ over the period 1984-2007,18 highlighting the approach taken in the cases to issues involving the relationship between state practice on the one hand and either determination of the content of a CIL rule, or interpretation of a treaty, on the other. ${ }^{19}$ That Section will be organized according to the various ways the Court can deal with state practice. For example, it might rely heavily on state practice to decide a case turning on a point of CIL, or, conversely, pay no attention to existing state practice in such a case. The following Section will analyze the Court's performance as revealed in the case narratives. The last Section will conclude.

\section{STATE PRACTICE IN THE ICJ, 1984-2007}

As noted above, state practice is central to analysis of CIL questions, and can be relevant to treaty analysis as well. The following discussion will treat these two types of cases separately. These two subsections will then be further divided according to the way the Court dealt with state practice. Some cases involve more

17 See Land, Island and Maritime Frontier Dispute (El Sal. v. Hond., Nicar. intervening), 1992 I.C.J. 351, 586 (Sept. 11) ("The Chamber considers that... customary law contemplate[s] that such practice may be taken into account for purposes of interpretation ....").

18 This period was selected because 1984 was the year the application was filed in Military and Paramilitary Activities (Nicar. v. U.S.), 1986 I.C.J. 14 (June 27), a case which focused considerable attention on the Court's use of state practice.

19 In East Timor (Port. v. Austl.), 1995 I.C.J. 90 (Jun. 30), states' practice of concluding treaties with Indonesia capable of application in a territory, the status of which was in dispute, was relied on by the Court to show that those states had not read certain United Nations resolutions as requiring them not to recognize Indonesian control over the territory. Id. at 103. In Application of the Convention on the Prevention and Punishment of the Crime of Genocide (Bosn. E Herz. v. Yugo.), 1996 I.C.J. 595 (July 11), states' practice in recognizing the status of the head of state of Bosnia-Herzegovina by acknowledging the force of treaties bearing his signature was relied on as part of the reason to reject an argument that the head of state lacked capacity to formally approve Bosnia-Herzegovina's decision to bring the case. In both of these cases, state practice was relevant only as evidence of states' attitudes toward a particular fact situation, not as an element in the determination of the content of a rule of law. This Article therefore does not address these cases. 
than one type of analysis, and therefore will be discussed in more than one place.

\subsection{CIL}

\subsubsection{Introduction}

Article 38 of the Statute of the ICJ sets out the sources from which the Court is required to draw the legal rules it applies:

Article 38

1. The Court, whose function is to decide in accordance with international law such disputes as are submitted to it, shall apply:

a. international conventions, whether general or particular, establishing rules expressly recognized by the contesting states;

b. international custom, as evidence of a general practice accepted as law;

c. the general principles of law recognized by civilized nations;

d. subject to the provisions of Article 59, judicial decisions and the teachings of the most highly qualified publicists of the various nations, as subsidiary means for the determination of rules of law.

2. This provision shall not prejudice the power of the Court to decide a case ex aequo et bono, the parties agree thereto. ${ }^{20}$

According to the Statute, therefore, customary law is to be derived from the "general practice of states." The International Law Association has provided the following working definition of customary international law:

(i) Subject to the Sections which follow, a rule of customary international law is one which is created and sustained by the constant and uniform practice of States and other subjects of international law in or impinging upon their

\footnotetext{
20 I.C.J. Statute, supra note 2 , art. 38.
} 
international legal relations, in circumstances which give rise to a legitimate expectation of similar conduct in the future.

(ii) If a sufficiently extensive and representative number of States participate in such a practice in a consistent manner, the resulting rule is one of "general customary international law". Subject to Section 15, such a rule is binding on all States. ${ }^{21}$

Some sense of the ICJ's own sense of the application of Article 38(1)(b) is provided by its decision in the North Sea Continental Shelf Cases (F.R.G. v. Denmark; F.R.G v. Netherlands). 22 Regarding the argument that the Convention on the Continental Shelf had passed into customary international law, the Court stated:

With respect to the other elements usually regarded as necessary before a conventional rule can be considered to have become a general rule of international law, it might be that, even without the passage of any considerable period of time, a very widespread and representative participation in the convention might suffice of itself, provided it included that of States whose interests were specially affected. ${ }^{23}$

Putting these two discussions together, it seems fair to argue that it is necessary that a significant number of states follow a practice before it can be labeled a rule of customary law. We also

21 Comm. on Formation of Customary (Gen.) Int'1 Law, Int'1 Law Ass'n, Final Report of the Committee: Statement of Principles Applicable to the Formation of General Customary International Law, 69 INT'L L. Ass'N REP. CONF. 712, 719 (2000).

22 North Sea Continental Shelf Cases (F.R.G. v. Den.; F.R.G. v. Neth.), 1969 I.C.J. 3 (Feb. 20).

$23 I d$. at 42. In this case, the Court held that the number of states adhering to the Convention at the relevant time was insufficient to establish that its rules had become CIL. There were thirty-nine parties to that Convention as of the date of the Court's decision. See U.N. Treaty Series, Convention on the Continental Shelf, http://treaties.un.org (follow "U.N. Treaty Series" hyperlink; scroll and select "Continental Shelf Convention"; select "see details"). Meanwhile the membership of the United Nations on that date (including land-locked states and others uninterested in the Convention, was 126. See United Nations, Growth in United Nations Membership, 1945-present, http://www.un.org/members /growth.shtml (last visited Dec. 3, 2009) (listing countries that joined the United Nations year by year). 
see that, in the opinion of the International Law Association, the practice must be uniform, which makes sense: it is difficult to characterize as a custom a practice some members of a group follow and other members of the same group do not.

At this point, a definition is necessary. The term "state practice" could conceivably be held to apply to anything done by someone who is part of the state apparatus. If the term is applied so broadly, however, it would seem to cover a large enough range of behaviors to confuse analysis; very different sorts of state action would be lumped together. Therefore, I propose to limit the use of the term "state practice" to behaviors respecting a particular issue that amounts to direct action by, or has a direct effect on, the state whose behavior is in question. For example, resolving a border dispute by sending military units to occupy the disputed border would clearly amount to state practice under this definition. So would a formal proclamation by which a state claimed the territory at issue, or a diplomatic protest of another state's occupying that territory. On the other hand, a state representative's vote in favor of a non-binding resolution in some international body taking a position on a border dispute to which the voting state was not a party would have no effect on that state, and would therefore not count under this definition. A fortiori, a state's vote for a nonbinding resolution purporting to establish general rules for addressing border disputes-since no specific issue would be involved - would likewise not count under this definition.

The reason for this distinction is to highlight the difference between behavior which a state's officials should see as committing the state in some way and behavior not likely to be seen by such officials as a commitment. In the former case, the state has to be prepared to deal with other states' reactions to its behavior. In the latter, there may well be no reactions to consider. Clearly then, a state must carefully consider behaviors of the first sort, while one cannot assume that state officials will seriously ponder the consequences of behaviors of the second sort.

Finally, note Article 38(1)(d) of the I.C.J. statute. That provision permits the Court to rely on judicial opinions and scholarly commentary, but only as subsidiary means of determining the content of international law. Those sources, that is, are not equivalent to the general practice of states. Further, reliance on judicial decisions is made subject to Article 59 of the Statute, which 
provides that the Court's decisions have "no binding force except between the parties and in respect of that particular case." 24 Stare decisis, in other words, is rejected as a generator of rules of international law.

In examining the Court's decisions regarding customary international law, then, we would expect the Court to derive the rules it applies from commitment-generating state behavior.

\subsubsection{CIL Cases - Rule of Decision Derived from Description of State Practice}

While the ICJ decided a number of cases during this period on the basis of CIL, only one turned on a rule of CIL which the Court derived from explicitly described state practice. Two others relied on more or less generally described state practice as one of the sources of the rule applied, but relied on non-practice based sources as well. Finally, the Court decided one case based on the absence of state practice supporting the rule for which the applicant contended.

The case turning on a rule derived from state practice was Legality of the Threat or Use of Nuclear Weapons, Advisory Opinion (Nuclear Weapons Case). ${ }^{25}$ That case was produced in response to the General Assembly's December, 1994, question: "Is the threat or use of nuclear weapons in any circumstance permitted under international law?"26

The Court first addressed the question whether any treaty clearly prohibited the use of or threat to use nuclear weapons, concluding, as will be discussed in more detail below, that none did. ${ }^{27}$ The Court then moved on to examine the customary law on the subject. It initially took the orthodox position that the substance of customary law depended mainly on state practice and state views of opinio juris. ${ }^{28}$ States arguing against the legality of nuclear weapons had asserted that the fact of their non-use subsequent to World War II established a customary rule of

24 I.C.J. Statute, supra note 2, art. 59.

25 Legality of the Threat or Use of Nuclear Weapons, Advisory Opinion, 1996 I.C.J. 226 (July 8) (Nuclear Weapons Case).

26 Id. at 227-28.

27 Id. at 247-53. See also infra notes 249-52 and accompanying text. (discussing the Court's method of interpreting treaties asserted to prohibit the threat or use of nuclear weapons).

28 Nuclear Weapons Case, 1996 I.C.J. at 253. 
prohibition, while those taking the opposite view stressed the significance of the reliance on nuclear weapons for deterrence. ${ }^{29}$ In rejecting the argument that this history established a customary law prohibition, the Court stated:

The Court does not intend to pronounce here upon the practice known as the "policy of deterrence." It notes that it is a fact that a number of States adhered to that practice during the greater part of the Cold War and continue to adhere to it. Furthermore, the members of the international community are profoundly divided on the matter of whether non-recourse to nuclear weapons over the past 50 years constitutes the expression of an opinio juris. Under these circumstances the Court does not consider itself able to find that there is such an opinio juris. ${ }^{30}$

Nuclear weapons opponents also put forward certain General Assembly resolutions as confirming a customary law prohibition on such weapons. The Court responded to this point by acknowledging that such resolutions "can, in certain circumstances, provide evidence important for establishing the existence of a rule or the emergence of an opinio juris,"31 but asserted that whether any particular resolution should be understood as having this effect depended on the resolution's content, on the circumstances of its adoption, and on whether opinio juris existed regarding the resolution's status. ${ }^{32}$ The resolutions in question here, the Court held, could not be seen as demonstrating an opinio juris with respect to nuclear weapons because substantial numbers of states either voted against their adoption or abstained on the matter. ${ }^{33}$

Turning finally to international humanitarian law, the Court asserted that the principal treaties in the field have entered customary law, relying in part on the extensive number of parties to those treaties and on the fact that no state had ever taken advantage of the denunciation clauses of those treaties. ${ }^{34}$ The

\footnotetext{
29 Id. at $253-54$.

$30 I d$. at 254 (italics in original).

31 Id. at 254-55 (italics in original).

32 Id. at 255.

33 Id.

34 Id. at 257-58.
} 
question then became whether customary international humanitarian law derived from those treaties rendered illegal the threat or use of nuclear weapons. The Court specifically addressed the effect on CIL of Additional Protocol 1 to the 1949 Geneva Conventions $^{35}$ (treating the matter as one of CIL presumably because of the protocol's non-ratification by three of the five nuclear powers) concluding that the conference which drafted that treaty produced no substantive debate on nuclear weapons and adopted no provisions addressed to them, and that the Additional Protocol therefore did not affect otherwise subsisting customary law regarding nuclear weapons. ${ }^{36}$

The Court finally confronted squarely the question of the compatibility of nuclear weapons with purely customary international humanitarian law. Its response was to evade the question. On the one hand, the Court observed that it could not pass on the argument that nuclear weapons could lawfully be used in certain limited circumstances, since the proponents of that view could not be precise in identifying those circumstances. ${ }^{37}$ On the other hand, the Court-though observing that the use of nuclear weapons "seems scarcely compatible with respect" for humanitarian law principles - concluded that it lacked the basis for concluding that the use of nuclear weapons could never be lawful. The Court fortified this conclusion by reference to the fundamental character of a state's right to survival and thus of its right to selfdefense in circumstances threatening its survival, on deterrence as a matter of state practice, and on the reservations by nuclear weapons states to the various treaties addressing those weapons, under which those states reserved the right to use such weapons in defined circumstances. 38

Ultimately, with respect to the crucial issue in the case, the Court's conclusion, expressed in paragraph 2(e) of the disposition in this case, was

that the threat or use of nuclear weapons would generally be contrary to the rules of international law applicable in

35 Protocol Additional to the Geneva Conventions of 12 August 1949, and relating to the Protection of Victims of International Armed Conflicts (Protocol 1), June 8, 1977, 1125 U.N.T.S. 3.

36 Nuclear Weapons Case, 1996 I.C.J. at 259.

37 Id. at 262

38 Id. at 262-63. 
armed conflict, and in particular the principles and rules of humanitarian law;

However, in view of the current state of international law, and of the elements of fact at its disposal, the Court cannot conclude definitively whether the threat or use of nuclear weapons would be lawful or unlawful in an extreme circumstance of self-defence, in which the very survival of a State would be at stake . . . 39

Paragraph 2(e) was adopted only by the casting vote of the President, showing how deeply divided the Court was regarding this case; indeed, the scope of the division may have been even greater than this result suggests. ${ }^{40}$ Nonetheless, the Court as a body was unwilling to ignore states' actual behavior regarding an issue as fundamental as the legality of nuclear weapons.

The first case relying on state practice as one among several sources of CIL rules was Continental Shelf (Libyan Arab Jamahiriya v. Malta).41 The parties in this case sought from the court a delimitation between their continental shelves, agreeing that their dispute had to be resolved according to CIL as it related to such delimitations. ${ }^{42}$

The Court relied solely on state practice in parts of its judgment. Regarding the issue of the place in customary law of a

39 Id. at 266.

40 All fourteen judges hearing this case wrote separate opinions. Id. at 268593. Given the outcome, it is surprising to note that eight of them seem to have been unwilling to treat state practice regarding nuclear weapons, as well as the implications of various treaties and Security Council resolutions on the subject, as controlling the question of the legality of the use of those weapons. Instead, most of these eight (all but Judge Herczegh), put controlling weight on some combination of ethical or general legal principles, General Assembly resolutions, or the asserted irrelevance of state practice. Id. at 269-70 (declaration of Bedjaoui, Pres.); id. at 275 (declaration of Herczegh, J.); id. at 278 (declaration of Shi, J.); id. at 280-81 (declaration of Vereshchetin, J.); id. at 282-83 (declaration of Ferrari Bravo, J.); id. at 287, 291 (separate opinion of Guillaume, J.); id. at 294-97 (separate opinion of Ranjeva, J.); id. at 309 (separate opinion of Fleischhauer, J.); id. at 31128 (dissenting opinion of Schwebel, Vice-Pres.); id. at 345-64 (dissenting opinion of Oda, J.); id. at 380-89, 392-97, 399-428 (dissenting opinion of Shahbuddeen, J.); $i d$. at 452-87, 494-96, 513-20, 532-42, 553 (dissenting opinion of Weeramantry, J.); $i d$. at 556, 558-71, 575-76, 578-79 (dissenting opinion of Koroma, J.); id. at 591 (dissenting opinion of Higgins, J.).

41 Continental Shelf (Libya v. Malta), 1985 I.C.J. 13 (June 3).

42 Id. at 29. 
boundary's distance from the relevant coasts as a criterion for shelf boundary delimitation, the Court stated: "that, apart from [provisions of the U.N. Convention on the Law of the Sea], the institution of the exclusive economic zone, with its rule on entitlement by reason of distance, is shown by the practice of States to have become a part of customary law ..." 43 In discussing its rejection of the proposition that, at least as a first step, a proposed boundary line should be one on which every point was equally distance from the coasts of the states in question (an equidistance line), the court acknowledged that the parties had brought to its attention over seventy shelf delimitation agreements. It went on to state, however, that, although state practice on this subject was important, the agreements, taken together, fell short of proving that use of an equidistance line or any other method was mandatory, though they did show that such a method could yield an equitable result in many circumstances. ${ }^{44}$

State practice, albeit unspecified, was one of several sources on which the Court relied in other portions of the opinion: that rejecting Libya's assertion that the size of a state's landmass was relevant to shelf delimitation, ${ }^{45}$ that disagreeing with the argument that the ratio of the lengths of the coastlines of the relevant states should determine the proportion of the shelf each would receive, ${ }^{46}$ and in holding that, if an equidistance line is used as the first stage of the exercise, it could subsequently be modified. ${ }^{47}$

Arrest Warrant of 11 April 2000 (Democratic Republic of the Congo v. Belgium) (DRC v. Belgium) was the other case treating state practice as one of several possible sources of CIL.48 In that case, the Democratic Republic of the Congo ("DRC") alleged that Belgium had incurred responsibility to the Congo by issuing an international warrant for the arrest of the then-sitting foreign minister of the Congo-not present in Belgium at the time-in respect of grave breaches of international humanitarian law allegedly committed by the minister on the territory of the

\footnotetext{
43 Id. at 33 .

44 Id. at 38.

45 Id. at 40-41.

46 Id. at 45.

47 Id. at 48.

48 Arrest Warrant of 11 April 2000 (Dem. Rep. Congo v. Belg.), 2002 I.C.J. 3

(Feb. 14) (DRC v. Belgium).
} 
Congo. ${ }^{49}$ After concluding that a sitting foreign minister enjoys full immunity from criminal prosecution, ${ }^{50}$ the Court asked if there were an exception to this rule with respect to accusations of war crimes or crimes against humanity. It was at this point that state practice figured in the Court's analysis. Specifically, the Court observed that it had considered the "few decisions of national higher courts," including two cases cited by the parties decided respectively by the House of Lords and the Court of Cassation of France, but not indicating whether it considered other cases as well. It also stated that it had considered unspecified national legislation. In addition to its references to these examples of state practice, the Court cited to the legal instruments creating international criminal tribunals and decisions of certain of those tribunals. On the basis of all of these materials, the Court stated that it found no exception to the rule of immunity before national courts with respect to sitting foreign ministers. ${ }^{51}$

Finally, the case putting weight on the absence of state practice supporting the applicant was Ahmadou Sadio Diallo (Republic of Guinea v. Democratic Republic of the Congo), (Preliminary Objections) (Diallo Case);52 the case also involved arguments based on subsidiary means for the determination of rules of law.

Guinea brought this case as a matter of diplomatic protection to seek reparation on behalf of one of its nationals and certain private corporations of which this national was the sole share-holder but which were chartered in the DRC.53 Guinea sought to establish that, as a matter of customary law, a state was permitted to exercise diplomatic protection on behalf of such corporations, relying on dictum from an ICJ case, a number of arbitral opinions, and the fact that many bilateral and multilateral treaties relating to the protection of foreign investment permit such representation. ${ }^{54}$ The Court rejected Guinea's argument, stating that it had examined "State practice and decisions of international courts and tribunals" but found no exception to the usual rule that states may

\footnotetext{
49 Id. at 9-10.

50 Id. at 20-22.

51 Id. at 23-24.

52 Preliminary Objections, Ahmadou Sadio Diallo (Guinea v. Dem. Rep. Congo) 46 I.L.M. 712 (Diallo Case).

53 Id. at 716.

54 Id. at 731-32.
} 
exercise diplomatic protection only on behalf of nationals. ${ }^{55}$ It went on to observe:

The fact invoked by Guinea that various international agreements, such as agreements for the promotion and protection of foreign investments and the Washington Convention, have established special legal régimes governing investment protection, or that provisions in this regard are commonly included in contracts entered into directly between States and foreign investors, is not sufficient to show that there has been a change in the customary rules of diplomatic protection; it could equally show the contrary. The arbitrations relied on by Guinea are also special cases, whether based on specific international agreements between two or more States, including the one responsible for the allegedly unlawful acts regarding the companies concerned... or based on agreements concluded directly between a company and the State allegedly responsible for the prejudice to it . . . 56

The Court in this case applied a fairly rigorous standard to determine what counted as state practice regarding diplomatic protection.

\subsubsection{CIL Cases: State Practice Available, but Rule of Decision Derived from Other Sources}

In a number of cases, the Court has determined that a rule of CIL existed without referring to state practice, even though practice existed and supported its result. Rather, the Court asserted that sources other than state practice had given rise to a rule of law. In some of these cases, some of those other sources could be characterized as "subsidiary means for the determination of a rule of law" under Article 38 of the statute, 57 while other sources on which the Court relied do not seem to fall within any of the categories of Article 38.

The first such case during the period under discussion was styled Delimitation of the Maritime Boundary in the Gulf of Maine Area

\footnotetext{
55 Id. at 732

56 Id.

57 I.C.J. Statute, supra note 2, art. 38(1)(d).
} 
(Canada v. United States of America) (the "Gulf of Maine Case"). ${ }^{58}$ The parties had asked the Court to determine "the course of the single maritime boundary that divides the continental shelf and fisheries zones of Canada and the United States of America [in the Gulf of Maine]." 59

The Court observed the parties made no argument supporting the possibility of drawing such a boundary, simply assuming such a thing was possible, and concluded "there is certainly no rule of international law to the contrary." 60 In other words, the Court saw no legal problem presented by the desire of two states to claim fishing zones extending 200 miles out from their respective coasts. ${ }^{61}$ Although the concept of such zones was relatively new at the time of the ICJ decision, over 100 states had nonetheless made claims to economic control over zones 200 miles in breadth, these claims covered more than $85 \%$ of the area potentially subject to such claims throughout the world. ${ }^{62}$

However, the Court did not base its conclusion regarding CIL on this record of practice. Rather, the Court stressed that the Third United Nations Conference on the Law of the Sea adopted provisions establishing rules regarding the continental shelf and the exclusive economic zone without objection by any of the many states participating in that conference, that the United States had proclaimed an exclusive economic zone, and that Canada had indicated agreement with the concept. It proceeded in this fashion, moreover, even as it acknowledged that the treaty adopted by the Conference-the United Nations Convention on the Law of the

58 Delimitation of the Maritime Boundary in the Gulf of Maine Area (Can. v. U.S.), 1984 I.C.J. 246 (Oct. 12) (Gulf of Maine Case).

59 Id. at 261.

60 Id.

61 Id. at 277-78, 302 (discussing the claims of the United States and Canada over the delimitation of maritime boundaries).

62 See generally ROBERT W. SMITH, ExClusive ECONOMIC ZONE Claims (1986) (introducing various maritime claims made by different countries); see also Sea Around Us Project, Web Products: Countries' EEZ: Equatorial Guinea, http://www.seaaroundus.org/eez/summaryInfo.aspx?EEZ=226 (last visited Dec. 3, 2009); Sea Around Us Project, Web Products: Countries' EEZ: Madagascar, http:/ / www.seaaroundus.org/eez/summaryInfo.aspx?EEZ $=450$ (last visited Dec. 3,2009 ). The determination that claims covered more than $85 \%$ of the area potentially subject to claims for economic control throughout the world was made by subtracting the areas of the claimed zones of Equatorial Guinea and that of Madagascar from the total given by Smith. See SMITH, supra, at 6. 
Sea 63 ("UNCLOS") - was not yet in force and that a number of states were not likely to become parties to it. 64 In fact, as of the date of the Court's judgment, only thirteen states had become parties to the Convention, which did not attract the sixty ratifications required to enter it into force ${ }^{65}$ until 1993.66 It should be noted, however, that at the time of the Court's judgment, it was well known that the United States would not become a party to UNCLOS. ${ }^{67}$

A second case that could have but did not rely on state practice to support some of the CIL rules it applied was Continental Shelf. 68 In connection with the parties' acknowledgment that the case was controlled by CIL, the Court stated:

It is of course axiomatic that the material of customary international law is to be looked for primarily in the actual practice and opinio juris of States, even though multilateral conventions may have an important role to play in recording and defining rules deriving from custom, or indeed in developing them.... [I]t cannot be denied that the 1982 Convention is of major importance, having been adopted by an overwhelming majority of States; hence it is clearly the duty of the Court, even independently of the

63 United Nations Convention on the Law of the Sea, Dec. 10, 1982, 1833 U.N.T.S. 397 [hereinafter UNCLOS].

64 See Gulf of Maine Case, 1984 I.C.J. at 294 (stating that a number of states do not seem inclined to adopt the Convention adopted at the Law of the Sea Conference).

65 See UNCLOS, supra note 20, art. 308 (requiring ratification by 60 states before treaty can enter into force).

66 U. N., Office of Legal Affairs, Division for Ocean Affairs and the Law of the Sea, Status of the United Nations Convention on the Law of the Sea, of the Agreement relating to the implementation of part XI of the convention and of the Agreement for the implementation of the provisions of the Convention relating to the conservation and management of straddling fish stocks and highly migratory fish stocks: Table Recapitulating the Status of the Convention and of the related Agreements, as at 1 October, 2009, http://www.un.org/Depts/los/reference _files/status2008.pdf (last visited Nov. 6, 2009). [hereinafter UNCLOS Status Table].

67 See U.S. Votes Against Law of the Sea Treaty, 82 DEP'T ST. BuLl. 71, 71 (1982) (quoting U.S. President Ronald Reagan) (declining ratification because the convention fails to address the United States objection to the deep seabed mining regime the convention adopts).

68 See generally Continental Shelf Case (Libya v. Malta), 1985 I.C.J. 3 (June 3) (applying customary international law without relying extensively on state practice for support). 
references made to the Convention by the Parties, to consider in what degree any of its relevant provisions are binding upon the Parties as a rule of customary international law. ${ }^{69}$

The Court also expressly stated that it was relying on the work of the Conference on the Law of the Sea, which produced the 1982 Convention. Thus, the Court cited the work of the Conference to support the conclusion that the "institution of the exclusive economic zone" had passed into CIL. It did not, however, refer to the fact of the proclamation of exclusive economic zones by a great many states. ${ }^{70}$ Rejecting Libya's assertion that the size of a state's landmass was relevant to shelf delimitation, the Court asserted a lack of support "in the work of the Third United Nations Conference on the Law of the Sea." 71 Similarly, the Court cited states' expression of their views at the Conference on the Law of the Sea, specifically the argument that the ratio of the lengths of the coastlines of the relevant states should determine the proportion of the shelf each would receive. ${ }^{72}$ In rejecting the argument that an equidistance line used as the first stage of delimitation cannot be modified, the Court relied on the Convention on the Continental Shelf, 73 and on the drafting history of UNCLOS. ${ }^{74}$

It is important to understand that only 19 states had ratified UNCLOS as of the date of the Court's judgment. ${ }^{75}$ The Court's statement that the convention was "adopted" by the overwhelming majority of states thus makes sense only if the Court is referring to the approval of the Convention text by the states participating in the Law of the Sea Conference-it cannot be referring to states' acceptance of the Convention as a binding treaty. Given the low level of formal acceptance of UNCLOS at this time, the Court's

69 Id. at 29-30 (italics in original).

70 Id. at 33 .

71 Id. at $40-41$.

72 See id. at 45 (discussing Libya's contention that proportionality should determine delimitation).

73 See generally Convention on the Continental Shelf, Apr. 29, 1958, 15 U.S.T. 471, 499 U.N.T.S. 311 (discussing delimitation of the continental shelf between states with shared boundaries).

74 See Continental Shelf Case, 1985 I.C.J. at 48 (citing the work of the Conference on the Law of the Sea to support its proposition).

75 UNCLOS Status Table, supra note 66. 
reliance on it and on the conference that produced it is somewhat surprising.

In another delimitation dispute, Maritime Delimitation in the Area between Greenland and Jan Mayen (Denmark v. Norway), ${ }^{76}$ the Court again refrained from relying on available state practice. In this case, the Court was asked to delimit the continental shelves and fishery zones of the Danish island of Greenland and the small Norwegian island of Jan Mayen, about 250 nautical miles to the east of Greenland. ${ }^{77}$ The Court concluded that CIL would control the delimitation of the fishery zone. ${ }^{78}$ However, in determining the applicable rule of CIL, the Court made no reference to the numerous state proclamations of exclusive economic zones. Instead, the Court cited the award of an arbitral tribunal made in 1977 and its own decision in the Continental Shelf Case to support its conclusion that the same principles governed both the shelf and the fishery zone delimitation. The Court also asserted that the provisions of UNCLOS relating to the delimitation of the continental shelf and the exclusive economic zone reflected the CIL on the subject but did not explain this conclusion even though it noted that UNCLOS had not yet come into force. ${ }^{79}$ The Court's subsequent references to the content of customary law in this case relied on judicial decisions, the language of treaties, and the work of the Third United Nations Conference on the Law of the Sea. 80

In Gabčikovo-Nagymaros Project (Hungary v. Slovakia), 81 the Court again failed to cite available practice to support a conclusion regarding the content of CIL. The case arose from a dispute over a 1977 treaty between Hungary and Czechoslovakia under which the parties had agreed to jointly construct a system of locks on the Danube, which formed their boundary.82 In October 1989, Hungary abandoned the project; it purported to terminate the treaty in May 1992. In April 1993, Hungary and Slovakia-as

\footnotetext{
76 See generally Maritime Delimitation in the Area between Greenland and Jan Mayen (Den. v. Nor.) (Denmark v. Norway), 1993 I.C.J. 38 (June 14) (relying on customary international law to settle dispute over delimitation).

77 Id. at $42-44$.

78 Id. at 56-58.

$79 \mathrm{Id}$. at 59.

80 Id. at 60-62.

81 Gabčíkovo-Nagymaros Project (Hung. v. Slovk.), 1997 I.C.J. 7 (Sept. 25).

82 Id. at 17-18 (setting out the nature of the dispute before the court and the matters provided for in the treaty).
} 
successor to Czechoslovakia - entered into an agreement to bring before the Court Slovakia's claim that Hungary had breached the 1977 treaty. 83

One of the issues in this case was whether Slovakia succeeded to Czechoslovakia's rights under the treaty. To resolve this point, the Court simply quoted the International Law Commission (ILC) to the effect that both traditional doctrine and modern opinion accept the rule that a succession of states does not affect treaties of a territorial character. ${ }^{84}$ The Court made no reference to the ILC's careful analysis of state practice supporting this proposition..$^{85}$

In Difference Relating to Immunity from Legal Process of a Special Rapporteur of the Commission on Human Rights, Advisory Opinion (Special Rapporteur Advisory Opinion), the Court again characterized a rule as CIL without reference to supporting practice. ${ }^{86}$ The General Assembly sought this advisory opinion to assist it in dealing with a dispute arising out of Malaysia's treatment of an individual who, at the relevant time, was serving as a Special Rapporteur of the Commission on Human Rights. ${ }^{87}$ It was argued that Malaysia's actions violated the treaty regulating the privileges and immunities of U.N. officials. In the course of examining the events giving rise to the case, the Court had occasion to assert that "the conduct of any organ of a State must be regarded as an act of that State." 88 Although it characterized that rule as customary, 89 the Court supported this conclusion only by reference to draft

83 Id. at $18,25,27,31-34$.

84 See id. at 72 ("[T]he International Law Commission identified 'treaties of a territorial character' as having been regarded both in traditional doctrine and in modern opinion as unaffected by a succession of States.") (citation omitted).

85 See Report of the International Law Commission to the General Assembly, U.N. Doc. A/9610/Rev. 1 (1974), reprinted in [1974] 2 Y.B. Int'1 L. Comm'n 154, 184-86, U.N. Doc. A/CN.4/SER.A/1974/Add.l, available at http://untreaty.un.org/ilc /documentation/english/A_9610.pdf (reviewing state practice and noting that often a successor state's willingness to continue the effect of treaties plays a role in whether or not those treaties remain in effect).

86 Difference Relating to Immunity from Legal Process of a Special Rapporteur of the Commission on Human Rights, Advisory Opinion, 1999 I.C.J. 62 (Apr. 29) [hereinafter Special Rapporteur Advisory Opinion].

87 See id. at 63-64 (reproducing the request from the Economic and Social Council for the I.C.J. to rule on a disagreement with Malaysia regarding immunity of Special Rapporteurs).

88 Id. at 87.

89 Id. 
articles on state responsibility provisionally adopted by the ILC..$^{90}$ It made no reference to state practice even though the ILC had included detailed analysis of state practice in its commentary on the relevant article. ${ }^{91}$

\subsubsection{CIL Cases - Judgment Based on Rules of Decision Derived from Subsidiary Sources}

In several cases decided in part on CIL grounds, the Court purported to derive rules of law wholly or partly from sources listed in Article 38(1)(d) of its statutes as "subsidiary means for the determination of rules of law." Included in this group are cases decided by the Court on the basis of rules it derived by analogy to established rules of international law.

Cases relying primarily on subsidiary sources include Land, Island and Maritime Frontier Dispute (El Salvador v. Honduras; Nicaragua intervening), a case involving disputes between El Salvador and Honduras over several portions of their land boundary and over their conflicting claims as to sovereignty over certain islands in the Gulf of Fonseca. ${ }^{22}$ The Court was also asked to determine the parties "legal situation" vis-à-vis both the Gulf itself and waters outside the Gulf. ${ }^{93}$

In resolving this case, the Court relied on certain black letter principles of international law, ${ }^{94}$ and on its own exegesis of these principles and those of other international tribunals and commentators. ${ }^{95}$ Indeed, at one point in the opinion it expressly

90 Id.

91 See Report of the International Law Commission to the General Assembly, U.N. Doc. A/9010/ Rev. 1 (1974), reprinted in [1973] 2 Y.B. Int'l L. Comm'n 161, 195, U.N. Doc. A/CN.4/SER.A/1974/Add.l, available at http:// untreaty.un.org/ilc /documentation/english/A_9010.pdf (referencing state practice in support of the claim that acts of a judicial branch could be viewed as attributable to the state).

92 Land, Island and Maritime Frontier Dispute (El Sal. v. Hond.; Nicar. intervening), 1992 I.C.J. 350 (Sept. 11).

93 Id. at 380 .

94 See id. at 386-87 (uti posseditis juris); id. at 546-49 (avulsion); id. at 586 (rule that treaty parties' practice may be used to interpret treaty; concept of historic bays).

95 See, e.g., id. at 387-401 (Arbitral Award of the Swiss Federal Council, International Court of Justice); id. at 563-65 (Arbitration of the Island of Palmas, Permanent Court of International Justice, International Court of Justice); id. at 589-93 (International Court of Justice, Central American Court of Justice); id. at 597 (Central American Court of Justice); id. at 600-01 (Central American Court of 
characterized its approach as one of relying on "subsidiary means for the determination of rules of law." 96 It cited no other type of authority even as it purported to apply CIL.97

In Territorial Dispute (Libyan Arab Jamahiriya v. Chad), 98 the Court was asked to determine the land boundary between Libya and Chad. ${ }^{99}$ In part, it based its judgment on international judicial decisions, including its own. ${ }^{100}$ Although the Court characterized as CIL a number of the other legal rules it applied in this case, it did not ground any of them in state practice.

In Hungary $v$. Slovakia, 101 the Court supported the conclusion that some of the rules the Vienna Convention on the Law of Treaties ${ }^{102}$ (Treaties Convention) stated customary international law solely by reference to its own opinions. ${ }^{103}$ Also, in considering the scope of riparian states' rights to use international rivers, it cited a decision by the PCIJ.104

In Kasikili/Sedudu Island (Botswana v. Namibia), ${ }^{105}$ the Court was faced with a territorial dispute which the parties agreed was controlled by a nineteenth century treaty between Great Britain and Germany, then the colonial powers controlling the areas in dispute. 106 The Court relied only upon its own jurisprudence in asserting the CIL status of Article 31 of the Treaties Convention, 107 including the language of that provision requiring reliance on

Justice, International Court of Justice); id. at 607-09 (Central American Court of Justice, International Court of Justice).

96 Id. at 601 .

97 See id. at 586 (stating that customary international law allows for the consideration of subsequent state practice in interpreting treaty terms).

98 Territorial Dispute (Libya v. Chad), 1994 I.C.J. 6 (Feb. 3).

99 Id. at 14.

100 See, e.g., id. at 23 (International Court of Justice); id. at 25 (Permanent Court of International Justice, International Court of Justice); $i d$. at 35 (treaties and charters of international bodies) (outlining Libya and Chad's respective requests for clarification of their boundaries).

101 Gabčíkovo-Nagymaros Project (Hung. v. Slovk.), 1997 I.C.J. 7 (Sept. 25).

102 Treaties Convention, supra note 16.

103 See Gabčíkovo-Nagymaros Project, 1997 I.C.J. at 38 ("[The court] needs only to be mindful of the fact that it has several times had occasion to hold that some of the rules laid down in that Convention might be considered as a codification of existing customary law.").

$104 \mathrm{Id}$. at 56.

105 Kasikili/Sedudu Island (Bots. v. Namib.), 1999 I.C.J. 1045 (Dec. 13).

106 Id. at 1049.

107 Treaties Convention, supra note 16, art. 31. 
subsequent practice of treaty parties as an aspect of treaty interpretation. ${ }^{108}$ The Court relied on statements by writers and determinations of arbitral tribunals to define a relevant term. ${ }^{109}$ It also relied on treaty practice in general to address several issues in the case. 110 The one treaty on which it specifically relied was cited to explain the Court's method of determining the proper measure of the width of a river; in this connection, the Court also cited a decision by the United States Supreme Court, and two arbitral awards. 111

Again, in the case concerning the Maritime Delimitation and Territorial Questions Between Qatar and Bahrain (Qatar v. Bahrain),112 the Court relied on a PCIJ decision for the proposition that Bahrain's limited activities on a disputed island were adequate to permit it to assert sovereignty, 113 applying that rule to resolve what it had described as an issue of CIL. ${ }^{114}$ It relied on its own cases in holding that the disputed island was so insignificant that it should not be given full effect with respect to the determination of the boundary between the parties' territorial seas. ${ }^{115}$ It also derived from its decisions the principles it applied to delimit a single boundary between the parties' continental shelves and exclusive economic zones, 116 and reasoned by analogy to established principles of maritime law to resolve the question of the effect of a low-tide elevation on a maritime delimitation. ${ }^{117}$

108 See Kasikili/Sedudu Island, 1999 I.C.J. at 1059 (noting that the parties agreed to the application of Article 31 "inasmuch as it reflects customary international law"); id. at 1075 (detailing the applicability of "subsequent practice" by the parties involved upon treaty interpretation under Article 31).

109 See id. at 1064 (pointing towards the treatment of the term "main channel" in scientific reports and arbitral decisions as potentially influential in defining the term).

110 See, e.g., id. at 1061-62 (noting that "various definitions of the term 'thalweg' are found in treaties delimiting boundaries and that the concepts of the thalweg of a watercourse and the centre of a watercourse are not equivalent.").

111 Id. at 1066.

112 Maritime Delimitation and Territorial Questions Between Qatar and Bahrain, (Qatar v. Bahrain), 2001 I.C.J. 40 (Mar. 16).

113 See id. at 100 (noting that in the past "the tribunal has been satisfied with very little in the way of the actual exercise of sovereign rights").

114 Id. at 91.

115 See id. at 104, 109 (noting the small size of the island in question and referencing past decisions discussing situations where such land might have a "disproportionate effect" with respect to its size on national boundaries).

116 See id. at 110-15 (describing this analysis).

117 Id. at 102-03. 
Sovereignty over Pulau Ligitan and Pulau Sipadan (Indonesia v. Malaysia) ${ }^{118}$ was a dispute over two small islands in the Celebes Sea. In addressing a relevant treaty, the Court once again repeated its ascription of CIL status to the rule that requires the Court to take account of treaty parties' practice when interpreting a treaty, relying solely on its own decisions. ${ }^{119}$ It also relied on its own decisions when, after concluding that a particular treaty did not apply to the islands in question, it enunciated the rules of law to be applied to the parties' arguments based on their respective activities relative to the islands. ${ }^{120}$

In yet another boundary case, Land and Maritime Boundary between Cameroon and Nigeria (Cameroon v. Nigeria; Equatorial Guinea Intervening), 121 the Court relied solely on its own decisions to determine a relevant legal standard.122 The Court supported its conclusion that Great Britain, during the time it claimed sovereignty over Nigeria as a colonial power, possessed the authority to conclude a treaty relevant to another issue by a very general reference to the practice of European powers regarding their African colonies, and by citations to an arbitral award and to two of its own decisions. The Court put forward no specific examples of state practice in this connection. ${ }^{123}$ Meanwhile, the Court resolved other issues in the case by relying on the practice of the parties and on the effect of certain actions taken by the United Nations during the period that the area in dispute was a Trust Territory; it decided still others by reference to arbitral awards and to certain of its own decisions. ${ }^{124}$

In addition to the foregoing, and as noted above, 125 the Court in the Arrest Warrant Case ${ }^{126}$ relied in part on the legal instruments

118 Sovereignty over Pulau Ligitan and Pulau Sipadan (Indon. v. Malay.), 2002 I.C.J. 625 (Dec. 17).

119 Id. at 645-46.

120 Id. at $668,678,682$.

121 Land and Maritime Boundary between Cameroon and Nigeria (Cameroon v. Nig.), 2002 I.C.J. 303 (Oct. 10).

122 Id. at 352-55, 401-16.

123 Id. at 404-07.

124 Id. at 407-16.

125 See supra text accompanying notes 48-51 (discussing the details of Dem. Rep. Conogo v. Belgium, a case treating state practice as one of several possible sources of CIL).

126 Arrest Warrant of 11 April 2000 (Dem. Rep. Congo v. Belg.), 2002 I.C.J. 3 (Feb. 14) (DRC v. Belgium). 
creating international criminal tribunals and to decisions of certain of those tribunals. ${ }^{127}$ As also discussed above, ${ }^{128}$ in the Diallo Case, ${ }^{129}$ the Court relied on draft articles produced by the International Law Commission and certain excerpts from its own decisions to define the concept of diplomatic protection, to establish the claimant state's obligation to establish either that such local remedies that were available were exhausted or that exceptional circumstances prevented exhaustion, and for proposition that it was for the respondent state to show that there were local remedies available but not exhausted. ${ }^{130}$

\subsubsection{CIL Cases - Authority for the Court's Judgment Either Not Apparent or Doubtful}

In five cases decided during this period, the Court either cited no basis for its assertions as to the content of CIL or relied solely on sources of law of questionable authority.

The first such case was Military and Paramilitary Activities in and against Nicaragua (Nicaragua v. United States of America), Merits ${ }^{131}$ (Nicaragua). Among the state practice issues that this case presented was one involving the concept of state practice itself. In its discussion of the nature of state practice sufficient to establish and maintain a rule of CIL, the Court stated:

The Court does not consider that, for a rule to be established as customary, the corresponding practice must be in absolutely rigorous conformity with the rule.... If a State acts in a way prima facie incompatible with a recognized rule, but defends its conduct by appealing to exceptions or justifications contained within the rule itself, then whether or not the State's conduct is in fact justifiable

\footnotetext{
127 Id. at 23-24.

128 See supra text accompanying notes 52-56 (discussing the details of the standard applied in the Diallo Case to determine what counted as state practice regarding diplomatic protection).

129 Ahmadou Sadio Diallo (Guinea v. Congo), Preliminary Objections, 46 I.L.M. 712.

130 Id. at 728-30.

131 Military and Paramilitary Activities (Nicar. v. U.S.), 1986 I.C.J. 14 (June 27).
} 
on that basis, the significance of that attitude is to confirm rather than to weaken the rule. ${ }^{132}$

In essence, the Court asserts that contrary practice does not undermine the existence of a rule of CIL so long as the state engaging in that practice proffers an explanation grounded in the rule, even, apparently, if that explanation is made in bad faith. Nothing in the Court's opinion qualifies this assertion even for cases in which the bad faith of the acting state is patent. The Court cites no authority of any sort to support this statement of the law.

A second state practice issue in the case was identifying the content of the relevant rule of CIL. In a confusing passage, the Court noted the parties' agreement on the CIL status of the U.N. Charter's restrictions on the use of force, but nonetheless saw itself as obliged to verify the existence of opinio juris consistent with this position. It purported to find the necessary evidence in the General Assembly's adoption of its Declaration on Principles of International Law Concerning Friendly Relations and CoOperation Among States ${ }^{133}$ between states, asserting:

The effect of consent to the text of such resolutions cannot be understood as merely that of a "reiteration or elucidation" of the treaty commitment undertaken in the Charter. On the contrary, it may be understood as an acceptance of the validity of the rule or set of rules declared by the resolution by themselves. ${ }^{134}$

The Court did not explain why consent to the resolution must be understood as it asserts; it merely made the assertion. Similarly unexplained was the Court's conclusion that the United States itself had demonstrated opinio juris with respect to this CIL principle by its acceptance of two non-binding resolutions at international conferences and by ratifying a regional treaty. ${ }^{135}$

This case also required the Court to determine the legal responsibility of the United States for the acts of the contra

132 Id. at 98.

133 Declaration on Principles of International Law Concerning Friendly Relations and Co-operation Among States in Accordance with the Charter of the United Nations, G.A. Res. 2625 (XXV), U.N. Doc. A/8082 (Oct. 24, 1970) [hereinafter Declaration on Friendly Relations].

134 Military and Paramilitary Activities, 1986 I.C.J. at 100.

135 Id. 
guerrillas directed against Nicaragua. ${ }^{136}$ The Court resolved the issue as follows:

The Court has taken the view... that United States participation, even if preponderant or decisive, in the financing, organizing, training, supplying and equipping of the contras, the selection of its military or paramilitary targets, and the planning of the whole of its operation, is still insufficient in itself ... for the purpose of attributing to the United States the acts committed by the contras in the course of their military or paramilitary operations in Nicaragua.... For this conduct to give rise to legal responsibility of the United States, it would in principle have to be proved that that State had effective control of the military or paramilitary operations in the course of which the alleged violations were committed. ${ }^{137}$

The Court cited no authority for this standard.

The Nicaragua Court relied on other supposed CIL rules, the sources of which it did not explain, in addressing the United States's argument that, even if its behavior was otherwise unlawful, it was in any event justified as an exercise of collective self-defense with respect to actions taken by Nicaragua affecting other Central American states, particularly El Salvador.138 The Court acknowledged that the right of self-defense was a matter of customary law, citing the U.N. Charter and certain General Assembly declarations in support but making no reference to state practice. ${ }^{139}$ The Court therefore had to address the content of the customary law of self-defense. It noted that the United States' argument that it had engaged in lawful self-defense depended on the assertion by the United States that Nicaragua had perpetrated an armed attack on El Salvador; the Court, however, stressed that the actions of Nicaragua were said to have involved "provision of weapons or logistical or other support"140 and asserted that such actions, though they could amount to a threat of force or an intervention, could not be considered armed attacks triggering the

\footnotetext{
136 Id. at 53-65.

137 Id. at $64-65$.

138 Id. at 72 .

139 Id. at 102-03.

140 Id. at 103-04.
} 
right of the victim of the attack to respond in self-defense. ${ }^{141}$ The Court did not explain the basis for this distinction.

The Court also stated that the right of a state to engage in collective self-defense on behalf of a second state depended on a request for such aid from the first state to the second, citing in reliance two inter-American treaties, and asserting that, apart from inter-American law, general international law imposed a similar requirement. ${ }^{142}$ Again, it provided no examples of state practice to demonstrate the existence of this requirement.

The Nuclear Weapons Case provides an example of reliance on sources whose law-making character is doubtful. In asserting that "States must take environmental considerations into account when assessing what is necessary and proportionate in the pursuit of legitimate military objectives," 143 the Court relied on a non-binding declaration made at a United Nations Conference, a General Assembly resolution, and an order the Court had made in an earlier case. ${ }^{144}$ It also relied on Articles 35(3) and 55 of the First Additional Protocol to the Geneva Conventions of 1949,145 forbidding the use of methods of warfare intended to or which may be expected to cause very severe, long-term environmental damage and requiring war-making states to protect against such damage; 146 however, the CIL status of these articles at the time of the Court's decision is unclear. ${ }^{147}$ If those articles were not CIL at

141 Id. at 104.

142 Id. at 104-05.

143 Threat or Use of Nuclear Weapons, Advisory Opinion, 1996 I.C.J. 226, 242 (July 8) (Nuclear Weapons Case).

144 Id. at 242-43.

145 Protocol Additional to the Geneva Conventions of 12 August 1949, and relating to the Protection of Victims of International Armed Conflicts (Protocol I) art. 35(3), art. 55, June 8, 1977, U.N.T.S. 17512.

146 Nuclear Weapons Case, 1996 I.C.J. 226, 242 (July 8).

147 Since there were 147 parties to the First Additional Protocol at the time of the Court's decision, one could argue that the number of ratifications alone would amount to sufficient state practice to establish a rule of CIL. See Table of Ratifications of Accessions to Protocol I, available at http://www.cicr.org/ihl.nsf /WebSign?ReadForm\&id=470\&ps=P (last visited Dec. 3, 2009). However, about one in five UN members were not parties to the Protocol at that time, including France, Japan, the United Kingdom and the United States, which casts some doubt on that conclusion. See United Nations, Member States of the United Nations, available at http://www.un.org/members/list.shtml (last visited Dec. 3, 2009). This doubt is reinforced by Professor Greenwood's questioning of the CIL status of the articles at issue, albeit in an article predating the Court's decision, 
the time of the Court's decision, the Court's conclusion regarding states' environmental duties in war time was thus based solely on reliance on non-binding instruments and on a treaty which did not codify CIL.

DRC v. Belgium ${ }^{148}$ also involved reliance on doubtful sources to determine the content of CIL. The Court saw this case as turning on the immunities international law afforded sitting foreign ministers from the jurisdiction of the courts of states other than their own. It acknowledged that the issue was a matter of CIL, though it cited treaties addressing closely related issues as providing "useful guidance."149 In its examination of CIL, the Court referred solely to functional considerations; it made no reference to state practice. Based on such considerations-and, presumably, by analogy to the treaties it had cited-the Court concluded that a sitting foreign minister enjoys both full immunity from criminal jurisdiction and personal inviolability. ${ }^{150}$ The Court closed its judgment by listing various sets of circumstances in which sitting foreign ministers could be prosecuted for war crimes and crimes against humanity. Only two involved international law. Again, the Court offered no authority supporting its conclusion with regard to them, though the rules it announced were analogous to those in the treaties it had previously cited.

In Gabčlkovo-Nagymaros Project ${ }^{151}$ the Court rested its discussion of riparian states' CIL rights to the use of international watercourses in part on the adoption of the Convention on the Law of Non-Navigable Uses of International Watercourses ${ }^{152}$ by the General Assembly, 153 even though that Convention has never come into force. ${ }^{154}$

Christopher Greenwood, Customary Law Status of the 1977 Geneva Protocols, in ESSAYS ON WAR IN INTERNATIONAL LAW 179, 190, 195 (2006).

148 Arrest Warrant of 11 April 2000 (Dem. Rep. Congo v. Belg.) (DRC v. Belgium), 2002 I.C.J. 3 (Feb. 14).

$149 \mathrm{Id}$. at 21.

150 Id. at 20-22.

151 Gabčíkovo-Nagymaros Project (Hung. v. Slovk.), 1997 I.C.J. 7 (Sept. 25).

152 United Nations Convention on the Law of the Non-navigational Uses of International Watercourses, G.A. Res. 51/229, Annex, U.N. GAOR, 51st Sess., Supp. No. 49, U.N. Doc. A/51/49 (May 21, 1997).

153 Gabčíkovo-Nagymaros Project, 1997 I.C.J. at 55-56.

154 International Water LaW Project, Status of the Watercourse CONVENTION (2008). 
Another unsourced judgment was Oil Platforms. ${ }^{155}$ In this case, Iran sought reparation for damage the United States had inflicted on three Iranian oil-drilling platforms in October, 1987, and April, 1988.156 The Court's jurisdiction was based on a 1955 Treaty of Amity between the United States and Iran providing that any disputes regarding "the interpretation or application" of the treaty were to be heard by the I.C.J. ${ }^{157}$ Iran alleged that the attacks on the platforms breached the treaty. The United States denied that the treaty had been breached, but also asserted that, in any event, the actions taken by the United States were permitted by an article of the treaty providing that the treaty "did not preclude the application of measures... necessary ... to protect [a party's] essential security interests."

The context of the actions at issue in this case was the Iran-Iraq war of 1980-88. During that period, there were a considerable number of attacks on neutral shipping plying the Persian/Arabian Gulf. On October 16, 1987, an American-flag vessel was struck by a missile while in the vicinity of Kuwait Harbor. The United States attributed the attack to Iran and, claiming self-defense, attacked two oil platforms on October 19. On April 14, 1988, an American warship struck a mine in international waters near Bahrain. The United States again blamed Iran and reacted by attacking Iranian installations, including a third oil platform, on April 20, again claiming self-defense. ${ }^{158}$

The Court stated that it would evaluate the self-defense claim by the United States "by reference to international law applicable to this question, that is to say, the provisions of the Charter of the United Nations and customary international law."159 With respect to each American use of force, the Court asked, first, whether the United States had proven that Iran had previously launched an attack, second, whether the attack could be considered an "armed attack" on the United States, and finally, whether the American

155 Case Concerning Oil Platforms (Iran v. U.S.) (Oil Platforms), 2003 I.C.J. 161 (Nov. 6)

156 Id. at $166,169-70$.

$157 \mathrm{Id}$. at 178.

158 Id. at $174-76$.

159 Id. at 183. Oddly, instead of first determining whether the actions of the United States breached the treaty, and then inquiring whether those measures were necessary to protect essential security interests - that is, first considering the claim, then turning to the affirmative defense - the Court elected to consider the defense first. 
responses could be said to satisfy tests of necessity and proportionality. 160 The Court concluded that the United States had failed to meet the burden of proving Iranian responsibility for either the October 16 or the April 14 attack. ${ }^{161}$ It also held that the actions of which the United States complained could not be labeled "armed attacks." With respect to the first incident, the Court noted that the United States characterized the missile strike on the tanker in Kuwait waters as part of a series of attacks to which the United States was responding. It held that these events, even taken together, did not amount to an armed attack on the United States, since the United States had not proven that the actions were specifically directed at United States targets (as opposed to being directed at an area where American-flag ships, among others, were known to operate).

Further, the Court seemed to doubt that these actions were sufficiently grave to amount to armed attacks. ${ }^{162}$ The court likewise held that the mining of the American warship did not constitute an armed attack to which the attacks on the oil platforms could be seen as a defensive response. Indeed, its language implied that an attack on a state's warship was not necessarily an armed attack on the state. ${ }^{163}$ The Court also held that neither American response met the necessity standard, observing that the United States had not complained to Iran of the use of the oil platforms, in contrast to the complaints the United States was acknowledged to have made regarding mining activity. ${ }^{164}$ Finally, the Court concluded that the October 19 attack might meet the proportionality standard, but held that the April 20 attack did not, holding that the damage done in the attack had to be in proportion to that suffered by the United States in the mining of the warship, as opposed to some other measure of proportionality. 165

The legal standard the Court applied therefore can be summed up as (1) a state cannot be the victim of an armed attack unless the action of which it complains is directed specifically at it, as

160 Id. at 189, 191-92, 195-96.

161 Id. at 189-90. The Court's analysis of the facts of this case was criticized by Judges Higgins, id. at 233-35 (separate opinion of Judge Higgins) and Buergenthal, $i d$. at 286-88 (separate opinion of Judge Buergenthal).

162 Id. at 191-92.

163 Id. at $195-96$.

164 Id. at 193-94, 198.

165 Id. at 198-99. 
opposed to being an indiscriminate attack that the attacker must have known could affect the state attacked; (2) an action, even by a state's military, is not an armed attack unless it rises to a sufficient level of gravity, even if the target is itself a military unit; (3) satisfying the necessity requirement of the doctrine of self-defense demands some sort of complaint by the defending state to the attacking state, even if there is good reason to doubt that the complaint would have any effect; and (4) the proportionality of an action taken in self-defense is evaluated by a comparison to the action to which it was a response, not by comparing it to the danger the defending state seeks to avoid. These conclusions have been criticized as misstating the law. 166 For present purposes, what is important is that the Court made no reference to any state practice in reading the foregoing limitations into what it apparently considered the CIL rules regarding self-defense, indeed, it did not make clear the source of those limitations.

The Wall Case ${ }^{167}$ was another in which many of the Court's conclusions were based on doubtful sources. That case addressed Israel's construction of a barrier (the wall) intended to block infiltration by terrorists across Israel's de facto 1967 eastern border (the Green Line) from the occupied Palestinian territories. ${ }^{168}$ The Court stated in the opinion that

[T] he rules and principles of international law which are relevant in assessing the legality of the measures taken by Israel ... can be found in the United Nations Charter and certain other treaties, in customary international law and in the relevant resolutions adopted pursuant to the Charter by the General Assembly and the Security Council. ${ }^{169}$

Since General Assembly Resolutions are not legally binding, this statement makes explicit that the Court was relying on sources hard to reconcile with Article 38. The Court grounded its assertion that international law renders illegal any acquisition of territory by force on the Charter, a General Assembly resolution, and language from Nicaragua, Merits. 170 To support the statement that the right

166 See, e.g., Taft, supra note 10, at 299-306 (analyzing the elements of selfdefense in international law).

167 Legal Consequences of the Construction of a Wall in Occupied Palestinian Territory, Advisory Opinion (Wall Case), 2004 I.C.J. 136 (July 9).

168 Id. at $166-70$.

169 Id. at 171.

170 Id. 
to self-determination is a right erga omnes, relied on Articles 1 of the International Covenant on Civil and Political Rights ${ }^{171}$ and the International Covenant on Economic, Social and Cultural Rights, ${ }^{172}$ the Charter, a second General Assembly resolution, and three of its decisions. ${ }^{173}$ It relied on a judgment of the Nuremberg tribunal and one of its decisions in holding that the Hague Regulations of 1907174 had passed into customary international law. ${ }^{175}$ To support its conclusion that the Fourth Geneva Convention ${ }^{176}$ applied in the Palestinian territories, the Court once again cited its own cases for the proposition that Article 31 of the Treaties Convention had passed into customary international law, and on the travaux préparatoires of the Fourth Geneva Convention, a resolution of a meeting of the parties to that convention, a statement by the International Committee of the Red Cross ("ICRC"), various General Assembly and Security Resolutions, and a decision of the Supreme Court of Israel. ${ }^{177}$ (Oddly, the Court justified its reliance on the ICRC's interpretation of the Fourth Convention by reference to language in Article 142 of that treaty which provides, "[t]he special position of the International Committee of the Red Cross in this field shall be recognized and respected at all times." 178 That article, however, refers only to access by relief societies to protected persons; it does not address the ICRC's competence to interpret the Convention.) ${ }^{179}$ The court relied on the practice of the Human Rights Committee (the monitoring body established by the International Covenant on Civil and Political Rights) and on the travaux préparatoires of that instrument in holding that the

171 International Covenant on Civil and Political Rights art. 1, Dec. 16, 1966, 999 U.N.T.S. 171.

172 International Covenant on Economic, Social and Cultural Rights art. 1, Dec. 16, 1966, 993 U.N.T.S. 3.

173 Wall Case, 2004 I.C.J. at 171-72.

174 Convention (IV) Respecting the Laws and Customs of War on Land, Oct. 18, 1907, T.S. 539, 1 Bevans 631.

175 Wall Case, 2004 I.C.J. at 172.

176 Convention (IV) relative to the Protection of Civilian Persons in Time of War, Aug. 12, 1949, T.I.A.S. 3365, 6 U.S.T. 3516 (hereinafter Fourth Geneva Convention).

177 Wall Case, 2004 I.C.J. at 171-77.

178 Fourth Geneva Convention, supra note 176, art. 142.

179 Id. 
provisions of the Covenant apply in territory under the control of a party to the Covenant as a matter of belligerent occupation. ${ }^{180}$

Finally, the Court considered the possibility that Israel had available the defense of necessity; that proposition, too, was rejected. The Court, relying on its own decision which citied a draft by the International Law Commission, asserted that a state may not rely on a plea of necessity unless the action taken is "the only way for the State to safeguard an essential interest against a grave and imminent peril." 181 The Court maintained that it was, "not convinced that the construction of the wall along the route chosen was the only means to safeguard the interests of Israel against the peril which it has invoked as justification for that construction." 182

Several of the rules the Court labeled CIL in this case ${ }^{183}$ do not seem to satisfy the state practice requirement in Article 38 of the I.C.J. Statute. Indeed, at no point in its opinion did it make any reference to actual state practice other than in its citation to the Israeli Supreme Court's opinion in connection with the applicability of the Fourth Geneva Convention. It did, however, cite repeatedly to General Assembly resolutions, determinations by the Human Rights Committee and the International Law Commission, and once to a determination by the ICRC. ${ }^{184}$ While some of these bodies might count as subsidiary sources of law, no legal instrument grants any of them the authority to make rules binding in international law. The Court did not address the fact that one of these bodies - the International Law Commission-has expressed doubts about the competence of bodies such as the Human Rights Committee to definitively interpret the treaties they monitor, at least in the context of evaluating treaty reservations. ${ }^{185}$

180 Wall Case, 2004 I.C.J. at 177-80.

181 Id. at 194-95.

$182 \mathrm{Id}$. at 195. Though not really relevant to this discussion, it is impossible not to note that the discussion of the necessarily fact-specific issue of Israel's necessity argument is surprisingly brief and conclusory.

183 Id. at 171-73.

184 Id. at 171-79.

185 Int'l Law Comm'n, Rapport de la Commission du droit international, sur les travaux de sa quarante-neuvieme session, 12 mai-18 juillet 1997 [Report of the International Law Commission on the Work of Its Forty-ninth Session, 12 May-18 July 1997], 107, U.N. Doc. A/52/10 (1997). 
Armed Activities on the Territory of the Congo (Democratic Republic of the Congo v. Uganda) ${ }^{186}$ (DRC v. Uganda) also raises issues of the Court's reliance on sources not mentioned in Article 38. The Democratic Republic of the Congo ("DRC") sought relief from the presence of Ugandan troops in its territory after August 1998, when the DRC had allegedly ceased to consent to what had admittedly begun as a consensual presence. The DRC further alleged various human rights violations and other war crimes committed by Ugandan forces. Uganda claimed that, in the period between 1994 and 1997, the DRC was supporting anti-Uganda rebel groups based in the territory of the DRC and carrying out attacks in Ugandan territory, and that DRC support for such groups resumed in 1998. Uganda therefore asserted that its operations in the territory of the Congo were matters of lawful selfdefense. Uganda also counter-claimed against the DRC, asserting that the DRC had violated its duty of vigilance by tolerating the operations of anti-Ugandan armed groups on Congolese territory. ${ }^{187}$

The Court held that a state's obligations under human rights treaties apply to territory over which it acquired control during the course of an armed conflict. The Court relied solely on its own decision in the Wall case ${ }^{188}$ to support this proposition, not even considering the language of the human rights treaties that it deemed applicable. ${ }^{189}$

The Court also gave a doubtfully sourced response to the DRC's assertion that Uganda's alleged pillaging of the Congo's natural resources was a violation of the principle that a state enjoys permanent sovereignty over its natural resources. The Court agreed that this principle was a matter of customary international law, but relied solely on several General Assembly resolutions as support for that conclusion, 190 despite the lack of binding legal effect in General Assembly resolutions.

186 Armed Activities on the Territory of the Congo (Dem. Rep. Congo v. Uganda), Dec. 19, 2005, 45 I.L.M. 271, 280-284 (2006).

187 Id. at 329.

188 Id. at 317, para. 216 (citing Legal Consequences of the Construction of a Wall in Occupied Palestinian Territory, Advisory Opinion, 2004 I.C.J. 136, 178-81 (July 9)).

189 Id. at 317-18.

190 Id. at 322-23. 
Application of the Convention on the Prevention and Punishment of the Crime of Genocide (Bosnia and Herzegovina v. Serbia and Montenegro), Merits191 (Genocide Case) was another case in which the Court chose to rely on its own decisions as authority even in the face of counter-arguments. Bosnia and Herzegovina originally brought this case in 1993, alleging that the Federal Republic of Yugoslavia ("FRY"), which became Serbia and Montenegro, was responsible for committing genocide in Bosnia and Herzegovina. ${ }^{192}$ The CIL issue arose when the Court had to determine the standard to evaluate the degree of control Serbia and Montenegro exercised over groups found to have perpetrated genocide. Thereafter, the court could determine whether the genocide could be attributed to Serbia and Montenegro. ${ }^{193}$ In Nicaragua, the Court held that the acts of groups could be attributed to a state only if it exercised "effective control" of the groups, that is, if it "directed or enforced the perpetration" of the particular acts at issue. ${ }^{194}$ However, as the ICJ noted, the International Criminal Tribunal for the Former Yugoslavia ("ICTY") applied a different standard in Prosecutor $v$. Tadić. 195

In Tadić, the standard for evaluating the defendant's conduct depended on the applicability of a particular treaty, which only applied if the conflict in Bosnia-Herzegovina could be considered "international." Classifying the conflict as international depended on whether the acts of Bosnian-Serb military forces could be attributed to the FRY (as it then was). The ICTY acknowledged that the Court's "effective control" test had not been satisfied. It held, however, that the effective control test was not the proper legal standard for evaluating the connection between a government and a military unit not part of the state structure, holding instead the conduct of the unit could be attributed to the state so long as the state was in "overall control" of the unit-that is, so long as the state provided financing, equipment, and

191 Application of the Convention on the Prevention and Punishment of the Crime of Genocide (Bosn. \& Herz. v. Serb. \& Mont.), Feb. 26, 2007, 46 I.L.M. 188, 288 (2007) (Genocide Case).

192 Id. at 190.

193 Id. at 286-87.

194 Military and Paramilitary Activities (Nicar. v. U.S.), 1986 I.C.J. 14, 64-65 (June 27).

195 Prosecutor v. Tadić, Case No. IT-94-1-A, Judgment in the Appeals Chamber, ๆ 112 (July 15, 1999). 
participated in the planning and supervision of military operations. ${ }^{196}$ Most important was the mode of analysis employed by the ICTY. It first considered the logic of the concept of attribution, noting that states were responsible for even ultra vires conduct of their organs, and observing that, for attribution purposes, an organized, hierarchically structured group could be analogized more reasonably to a state organ than to an individual, for whom a more demanding attribution standard might be appropriate. ${ }^{197}$ The ICTY next examined in detail decisions by three international tribunals and one from the German courts (such a decision being a form of German state practice) which attributed state acts of hierarchically structured groups to the "overall control" standard. 198

In addressing the difference between its standard and that of the ICTY, the Court took note of the formulation on State Responsibility in the International Law Commission's Articles to the effect that the acts of persons or groups are attributed to a state if the person or group is "acting ... under the direction or control of" the state. The issue, however, was defining "control." After citing this language, the Court rejected the ICTY's standard because "it stretch[ed] too far, almost to the breaking point, the connection which must exist between the conduct of a State's organs and its international responsibility." 199 The Court did not explain why it reached this conclusion; it simply asserted it. Likewise, the Court did not acknowledge that the commentary on the relevant portion of the Articles on State Responsibility takes note of both the Nicaragua and Tadic cases, but does not choose between them. ${ }^{200}$ Nor did the ICJ engage the arguments made by the ICTY, including the arguments drawn from judicial decisions and state practice. We are left, therefore, with nothing more than ipse dixit to support the ICJ's result.

$196 \quad$ Id. ๆ 145.

197 Id. ๆ $119,121$.

198 Id. ๆ $124-31$.

199 Genocide Case, 46 I.L.M. at 286-88.

200 Int'l Law Comm'n, Report of the International Law Commission on the Work of Its Fifty-third Session, 23 April-1 June and 2 July-10 August 2001, 103-09, U.N. Doc. A/56/10 (2001). 


\subsubsection{CIL Cases - Rule Applied Contradicted by Significant State Practice}

In four cases decided during this period, the Court's judgment relied on a rule of law contradicted by significant state practice. It is important to stress that the practice to which the Court appeared unwilling to give weight was not sporadic or attributable to lowlevel government officials, but frequent and the consequence of decisions by the highest level of government.

Two of these cases were the decisions involving the United States and Nicaragua, Military and Paramilitary Activities in and against Nicaragua (Nicaragua v. United States of America), Jurisdiction and Admissability 201 (Nicaragua, Jurisdiction) and Nicaragua, Merits. ${ }^{202}$ Nicaragua alleged in its application that the United States was responsible for certain unlawful uses of force against it. As noted above, $^{203}$ the ICJ's analysis in these judgments was and remains quite controversial. Accordingly, they will require some discussion.

In Nicaragua, Jurisdiction, the Court addressed arguments made by the United States against the ICJ's jurisdiction over Nicaragua's claims against it. The elements of the Court's analysis depended very little on state practice. One exception, however, concerned an element of the instrument by which the United States had accepted the court's so-called compulsory jurisdiction.

In that instrument, the United States excluded from its consent certain disputes arising under multilateral treaties.204 The United States argued that, since Nicaragua based its claims in part on the United Nations Charter, the case fell into the class of excluded disputes. ${ }^{205}$ The Court rejected this argument, observing that Nicaragua had also based its claims on allegations of violations of customary international law and "[p]rinciples such as those of the non-use of force, non-intervention, respect for the independence

201 Military and Paramilitary Activities in and Against Nicaragua, Jurisdiction of the Court and Admissibility of the Application (Nicar. v. U.S.), 1984 I.C.J. 392, 421-23 (Nov. 26) (Nicaragua, Jurisdiction). 27).

202 Military and Paramilitary Activities (Nicar. v. U.S.), 1986 I.C.J. 14, 16 (June

203 See supra text accompanying notes 6-10 (citing commentators' negative reactions and strong criticism of the court's decisions in Nicaragua, Merits, the Wall Case, and Oil Platform).

204 Nicaragua, Jurisdiction, 1984 I.C.J. at 421-23.

205 Id. at 422. 
and territorial integrity of States and the freedom of navigation, continue to be binding as part of customary international law ..."206 While this assertion presumably must be understood to mean that the Court saw these principles as representing the general practice of states, it did not explicitly address the question of whether the state practice in fact conformed to those principles. Rather, it simply asserted their character as customary law.

This argument was also crucial to the Court's Judgment in Nicaragua, Merits, ${ }^{207}$ aspects of which have already been addressed. The Court in that case repeated its assertion that Article 2(4) of the U.N. Charter, forbidding "the threat or use of force against the territorial integrity or political independence of any state," 208 was a rule of customary international law. ${ }^{209}$ But the Court cited no state practice whatever supporting this conclusion. While the Court argued that the opinio juris supporting this proposition of law had to be established and attempted to do so, it did not analyze state practice. Furthermore, in attempting to establish opinio juris, the Court relied on a number of doubtful sources. ${ }^{210}$ These included the Declaration on Friendly Relations, the support of the United States for non-binding resolutions adopted by other bodies, the language of a treaty to which the United States was a party, frequent statements by state representatives, the work of the ILC, and statements by both of the parties in their memorials that the rule was one of jus cogens. ${ }^{211}$ The Court's use of statements from both parties' memorials is somewhat confusing in light of the Court's earlier insistence that it was obliged to determine the law on this subject independent of the parties' positions. ${ }^{212}$ The Court also relied on the Declaration on Friendly Relations as establishing the grounds for legal distinctions between uses of force constituting armed attacks and those which are less serious, and reinforcing the argument that armed intervention by one state in the internal affairs of a second state is a violation of a customary rule 213 -indeed, its focus on the language of this non-binding

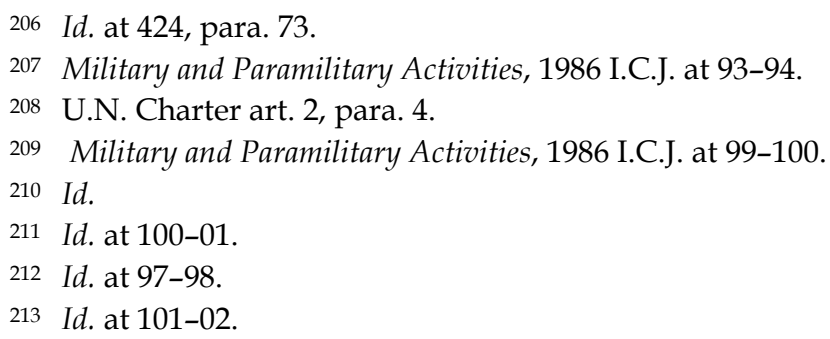


resolution in this context is hard to distinguish from what would be expected if the Court were construing a treaty.

By characterizing the foregoing actions as establishing a CIL rule, the Court effectively attributed no legal effect to states' interventions in the internal affairs of other states, a type of action which took place frequently during the 1970's and 1980's; one count showed 18 such interventions. ${ }^{214}$ The Court acknowledged this fact, stating that "there have been in recent years a number of instances of foreign intervention for the benefit of forces opposed to the government of another state." 215 However, the Court proffered two reasons for according no legal significance to these interventions. First, it stated that it "is not concerned here with the process of decolonization; this question is not at issue in the present case."216 The implication, of course, is that there is some legally relevant distinction between interventions in aid of decolonization and all others, such that the latter can be considered without reference to the former. The Court, however, did not explain the basis of any such distinction.

The Court offered a second reason for disregarding the interventions to which it referred: the intervening states offered no legal rationale for their behavior. ${ }^{217}$ Citing its opinion in North Sea Continental Shelf, 218 the court asserted that practice was not enough to establish a new rule of customary law. Also required was "evidence of a belief that this practice is rendered obligatory by the existence of a rule of law requiring it. The need for such a belief, i.e., the existence of a subjective element, is implicit in the very notion of the opinio juris sive necessitatis." 219

In the case of interventions, however, "States had not justified their conduct by reference to a new right of intervention or to a new exception to the principle of its prohibition."220 According to the Court, the United States, in particular, had justified its actions

214 A. Mark Weisburd, Use of Force: The Practice of States Since World WAR II 120-28, 139-41, 143-50, 152-66, 179-82, 184-86, 188-96, 198-202, 203-06, 226-40 (1997).

215 Id. at 108.

216 Id.

217 Id. at 108-10.

218 North Sea Continental Shelf Cases (F.R.G. v. Den.; F.R.G. v. Neth.) 1969 I.C.J. 3 (Feb. 20).

219 Id. at 44 (internal citation omitted), quoted in Military and Paramilitary Activities, 1986 I.C.J. at 109.

220 Military and Paramilitary Activities, 1986 I.C.J. at 109. 
regarding Nicaragua in statements of policy; it had not asserted new rules of international law. ${ }^{221}$ Therefore, the Court held that such interventions and therefore the actions of the United States toward Nicaragua, were unlawful. ${ }^{222}$

Since part of the purpose of this Article is to examine the quality of the ICJ's decisions, it is important to note several crucial flaws in its reasoning on this point. In the first place, its approach assumed the existence of the rule against intervention, and asserted that the evidence was insufficient to permit the conclusion that the rule had changed; the more basic question, however, was whether the rule on which the Court relied had ever come into existence, in light of contrary state practice, or, if it had, whether it continued to exist. Second, the Court's approach did not distinguish between the evidence required to demonstrate the existence of a restriction on state freedom - the issue in the North Sea Case 223 - and that necessary to show the absence of any such restriction. Finally, the Court was clearly incorrect in its assertion that states engaged in interventions in the affairs of other states had never offered legal justifications for their actions.224

221 Id.

222 Id. at 109-10, 118-19, 124.

223 See North Sea Continental Shelf Case, 1969 I.C.J. at 3 (discussing whether customary international law obliged Germany to accept an equidistance line as the method of delimiting the boundaries between its continental shelf and those of its neighbors).

224 France intervened in Gabon in 1964 to suppress a military coup, justifying its action by reference to a mutual defense treaty between the two states addressing internal as well as external defense. See WEISBURD, supra note 214, at 219. After the intervention by the United States in the midst of the civil disorder in the Dominican Republic beginning in April, 1965, Lyndon Johnson, then President of the United States, strongly endorsed the principle of non-intervention by states into the internal affairs of other states; however, he defended the Dominican intervention in part by relying on a 1962 resolution of an organ of the Organization of American States and also by characterizing interventions aimed at preventing the establishment of Communist governments in the Western Hemisphere as an exception to the non-intervention principle. Lyndon B. Johnson, Statement of President Johnson (May 2, 1965), reprinted in DEP'T. ST. Bull., May 17, 1965, at 744, 746-47. That is, he did not simply misrepresent the actions the United States had taken. Again, in November, 1968, after the Warsaw Pact states had invaded Czechoslovakia the previous August in order to replace that country's liberal Communist government, WEISBURD, supra note 214, at 22426, Leonid Breznhev, then General Secretary of the Communist Party of the Soviet Union, defended the invasion in a speech arguing that, notwithstanding the general rule that interventions in internal affairs were unlawful, international law as understood by the Soviet Union allowed interventions undertaken to prevent the weakening of the socialist system. Leonid Brezhnev, General Secretary, 
In its two Nicaragua judgments, then, the ICJ was unwilling to accord state practice the status apparently required by Article 38 in analyses of CIL, preferring to rely on sources of law not mentioned in Article 38 and not binding on their own terms. ${ }^{225}$

The Court also ignored relevant practice in three other cases. As noted above,226 the Court in the Oil Platforms Case 227 applied a very stringent test for determining whether the United States could rely on the defenses of self-defense and necessity with respect to its attacks on Iranian oil platforms. However, the Court did not inquire whether the response of the United States and the United Nations to the attacks of September 11, 2001 had any bearing on the content of the law of self-defense.228 Since Security Council decisions are legally binding on all U.N. members, Council resolutions would appear to be a very important type of state practice. Yet the Court in Oil Platforms did not address Security Council Resolution 1378,229 which apparently endorses the overthrow of the Taliban regime as a response to the September 11

Communist Party of the Soviet Union, Speech before the fifth Congress of the Polish United Workers Party (Nov. 13, 1968).

225 Beyond these points, there is reason to wonder whether the Court was entirely unbiased in its consideration of this case. For example, it rejected the argument that El Salvador had in fact sought the assistance of the United States in defending itself as early as 1981, despite a clear statement to that effect in the Declaration of Intervention of the Republic of El Salvador, (Nicar. v. U.S.), 1984 I.C.J. 215, and despite the absence of evidence to the contrary. See Military and Paramilitary Activities, 1986 I.C.J. at 87-88, 120-22 (June 27). However, the Court refused to credit American assertions that the government of Nicaragua was supporting the groups seeking to overthrow the government of El Salvador, at least in part simply because Nicaragua denied the assertion, despite evidence supporting the American claims, id. at 78-79. More seriously, according to Judge Schwebel, in December, 1984, after the Court had rendered its judgment in Military and Paramilitary Activities, but before the withdrawal of the United States from its participation in the matter, then-President Elias not only gave an interview in which he commented on this pending case, but in the interview expressly criticized various aspects of the foreign policy of the United States, Military and Paramilitary Activities, 1986 I.C.J. at 314-15 (Schwebel, J., dissenting); in his separate opinion, Judge Elias acknowledged the accuracy of Judge Schwebel's account of the interview. Id. at 179-80 (separate opinion of Judge Elias).

226 See supra text accompanying notes 162-67.

227 Oil Platforms (Iran v. U.S.), 2003 I.C.J. 161, 189, 191-92, 195-96 (Nov. 6).

228 Professor Murphy stresses the importance of the Security Council resolutions adopted in response to those attacks as a measure of states' understanding of the scope of the right of self-defense. See Murphy, supra note 10, at 67-70.

229 S.C. Res. 1378, U.N. Doc. S/RES/1378 (Nov. 14, 2001). 
attacks 230 and thus provides at least some guidance as to states' understanding of the meaning of proportionality and necessity in the context of self-defense. This raises particular difficulties because the Court's apparent assumption that the proportionality of a defensive response is to be measured against the act prompting the resort to self-defense, rather than according to the extent of the future danger the defending state seeks to prevent, is hard to square with Resolution 1378.

The Court also ignored relevant practice in the advisory opinion in the Wall Case, ${ }^{231}$ when it held illegal, as a matter of customary law, both the seizure of territory by force and the denial of the right of self-determination. This holding is problematic because it is difficult to reconcile with the facts of East Timor.232 That case arose after Indonesia seized East Timor by force and subsequently annexed it, and after the rest of the world essentially acquiesced in that seizure, despite initially characterizing it as violating the right to self-determination. ${ }^{233}$ This pattern of events would seem to undercut any argument as to the character of CIL as the principles the Court applied, but the Wall opinion makes no reference to international reaction to Indonesia's actions in East Timor.

DRC v. Uganda 234 is another case in which the Court applied purported CIL rules at least arguably inconsistent with state practice. One such situation arose from the Court's dealing with the DRC's claims turning on the relationship between Uganda and certain Congolese groups rebelling against the government of the DRC. The Court concluded that, while Uganda had given training and military support to such groups, it had not controlled them. The Court, however, took note of language in the General Assembly's Declaration on Friendly Relations ${ }^{235}$ to the effect that

Every State has the duty to refrain from organizing, instigating, assisting or participating in acts of civil strife or terrorist acts in another State or acquiescing in organized

231 Id. pmbl., paras. 2, 4.

231 Legal Consequences of the Construction of a Wall in Occupied Palestinian Territory, Advisory Opinion, 2004 I.C.J. 136 (July 9).

232 East Timor (Port. v. Austl.), 1995 I.C.J. 90 (June 30).

233 Id. at 103-05.

234 Armed Activities on the Territory of the Congo (Dem. Rep. Congo v. Uganda), 45 I.L.M. 271, 307 (Dec. 19, 2005).

$235 \mathrm{Id}$. at 308. 
activities within its territory directed towards the commission of such acts, when the acts referred to in the present paragraph involve a threat or use of force. ${ }^{236}$

and that "no State shall organize, assist, foment, [or] finance... armed activities directed towards the violent overthrow of the regime of another State, or interfere in civil strife in another State." 237

The Court held that this language stated customary international law, citing no authority for that proposition, and relying only on its own decision in Nicaragua for the rule that the implication of this language is to forbid external support for internal opposition groups. The Court therefore concluded that Uganda's support for anti-government Congolese forces violated international law. 238 As it had done in Nicaragua, the Court placed no weight on the widespread practice of intervention; indeed, in DRC v. Uganda, it did not even acknowledge the fact of such interventions.

A second similar problem in this case was presented by Uganda's counterclaims. One of those counter-claims was based on the DRC's alleged lack of vigilance in tolerating the operations of anti-Uganda guerillas on the Congo's territory. That claim was based on the same elements of the Declaration on Friendly Relations that the Court cited as supporting the customary law rule forbidding states to so much as tolerate actions within their borders amounting to interference in the affairs of other states, and the Court acknowledged as much. It held, however, that the DRC was not responsible for "tolerating" the activities of these groups because of its practical inability to control the areas where they operated. ${ }^{239}$ The Court cited no state practice supporting such a limitation on the prohibition on which Uganda relied, failing once again to mention the post-September 11 Security Council resolutions; ${ }^{240}$ those resolutions, dealing as they do with a state's

236 Id. at 308.

237 Id.

238 Id. at 308.

239 Uganda was, thus, in the strange position of being forbidden to use force against insurgent groups as a matter of self-defense because their actions were not attributable to the DRC, see supra notes 285-86 and accompanying text. Uganda was also unable to hold the DRC responsible for failing to suppress these groups because of the weakness of the DRC government.

240 Id. 
responsibility for the actions of powerful groups operating from within its territory, were at least relevant state practice, and arguably inconsistent with the Court's result.

Finally, the Diallo Case ${ }^{241}$ presents an interesting twist on the Court's failure to confront contrary authority. In that case, the Court derived its definition of "diplomatic protection" 242 from the ILC's Draft Articles on Diplomatic Protection. ${ }^{243}$ Draft article 11 discusses the question of diplomatic protection of a corporation incorporated in the allegedly wrongdoing state, the shares of which are owned by nationals of the protecting state. The article provides that the protecting state may provide such protection if the incorporation was required as a condition of doing business. ${ }^{244}$ In the Commentary to that article, however, the ILC makes the case that such protection is allowed even if the incorporation was not required as a precondition to doing business, noting that its draft takes a position more conservative than is recognized in practice. ${ }^{245}$ The Court's opinion essentially rejects the reasoning of the ILC commentary, but does not acknowledge that its conclusion is at odds with the ILC's reasoning; it mentions draft article 11 only to note that the case was not one where local incorporation was forced on a foreign national. ${ }^{246}$

\subsection{Treaties}

Any discussion of the relationship between state practice and treaty interpretation must start with Article 31 of the Vienna Convention on the Law of Treaties. Article 31 provides, in relevant part:

\section{Article 31}

General rule of interpretation

1. A treaty shall be interpreted in good faith in accordance with the ordinary meaning to be given to the terms of the

241 Ahmadou Sadio Diallo (Guinea v. Congo), May 24, 2007, 46 I.L.M. 712.

242 Id. 722

243 See Report of the International Law Commission on the Work of its Fifty-Eighth Session, 22-65, U.N. Doc. A/RES/61/10 (2006) [hereinafter Diplomatic Protection Draft Articles].

244 Id. art. 11(b), at 58.

245 Id. at 62-65.

246 Diallo, 46 I.L.M. at 733. 
treaty in their context and in the light of its object and purpose.

$\cdots$

3. There shall be taken into account, together with the context:

(b) any subsequent practice in the application of the treaty which establishes the agreement of the parties regarding its interpretation .... ${ }^{247}$

That is, according to the Vienna Convention, the practice of treaty parties in applying the treaty is not merely a source of enlightenment which may be consulted or not, but a piece of evidence which must be considered in any case where it is available.

It must be stressed that the Court has repeatedly held that Article 31 has passed into CIL, and has relied on it in a number of cases.248 For example, in the Nuclear Weapons Case, ${ }^{249}$ the Court relied on the practice of treaty parties in interpreting several treaties. The Court observed that "the pattern" 250 regarding treaty prohibitions of weapons of mass destruction was for such weapons to be prohibited by specific instruments and noting that certain treaties asserted to make the threat or use of nuclear weapons illegal contained no such specific prohibition of those weapons. ${ }^{251}$ The Court also held that certain treaties addressed specifically to

247 Treaties Convention, supra note 16, art 31.

248 See Border and Transborder Armed Action: Jurisdiction of the Court and Admissibility of the Application (Nicar. v. Hond.), 1988 ICJ 69, 87-88 (Dec. 20) (regarding a multilateral treaty); Maritime Delimitation in the Area between Greenland and Jan Mayen (Den. v. Nor.), 1993 I.C.J. 38, 51-52 (June 14) (involving a bilateral treaty); Gabčíkovo-Nagymaros Project (Hung. v. Slovk.), 1997 I.C.J. 7, 38 (Sept. 25) (bilateral treaty); Kasikili/Sedudu Island (Bots. v. Namib.), 1999 I.C.J. 1045, 1059, 1075-76 (Dec. 13) (bilateral treaty); Sovereignty Over Pulau Ligitan and Pulau Sipadan (Indon. v. Malay.), 2002 I.C.J. 625, 645-46, 656-65 (Dec. 17) (bilateral treaty); Legal Consequences of the Construction of a Wall in Occupied Palestinian Territory 2004 I.C.J. 136, 172 (July 9) (multilateral treaty).

249 Legality of the Threat or Use of Nuclear Weapons, Advisory Opinion, 1996 I.C.J. 226 (July 8).

250 Id. at 248.

251 See id. at 248-49 (contrasting the treatment of nuclear weapons with that of other weapons of mass destruction). 
nuclear weapons could not be read to prohibit their possession or use. It based this conclusion in part on the language of those treaties, but also relied on the failure of treaty parties to object to certain reservations propounded by states possessing nuclear weapons, and on the Security Council's approval of the entire arrangement. ${ }^{252}$

The Court has even based interpretations of instruments accepting its jurisdiction and of its Statute on state practice. In Land and Maritime Boundary Between Cameroon and Nigeria (Cameroon v. Nigeria), (Preliminary Objections), ${ }^{253}$ Nigeria's preliminary objections included the assertion that there was no basis for a judicial determination regarding certain issues because Cameroon's submissions to the Court were so lacking in necessary details that Nigeria was unable to frame a reply to those submissions, because the Court would be unable to resolve the questions raised by those submissions, and because an applicant state was essentially restricted to arguments based on whatever allegations were set out in its application, with only limited scope for subsequent expansion. Cameroon responded that it intended to provide additional details in the course of the litigation and was free to do so under the rules of the Court.254

The Court rejected Nigeria's preliminary objection, relying in part on the implications of its own decisions. It also relied, however, on what it called "an established practice for States submitting an application to the Court to reserve the right to present additional facts and legal considerations." 255

In Fisheries Jurisdiction (Spain v. Canada), Jurisdiction, 256 the Court's jurisdiction depended on whether a reservation to Canada's acceptance of the Court's compulsory jurisdiction deprived the Court of jurisdiction in the case. The reservation excluded from its acceptance of the Court's compulsory jurisdiction "disputes arising out of or concerning conservation

252 Id. at 248-53.

253 Land and Maritime Boundary Between Cameroon and Nigeria (Cameroon v. Nig.), 1998 I.C.J. 275 (June 11).

254 See id. at 317-18 (detailing the claims made by both Nigeria and Cameroon with respect to Nigeria's Sixth Preliminary Objection).

255 Id. at 318.

256 Fisheries Jurisdiction (Spain v. Can.), 1998 I.C.J. 432 (Dec. 4). 
and management measures taken by Canada with respect to vessels fishing in [a designated ocean area]."257

In its analysis of this question, the Court determined that the crucial issue was the meaning of the term "conservation and management measures" as used in the reservation, and that the phrase should be given the meaning the meaning it had in international law. ${ }^{258}$ To determine this meaning, the Court relied on state practice, which it recounted with great specificity. In particular, it cited two international multilateral conventions, three regional multilateral conventions, two bilateral conventions and the domestic law of Algeria, Argentina, the Malagasy Republic, New Zealand and the European Economic Community. ${ }^{259}$

Finally, the Court held that it lacked jurisdiction in Aerial Incident of 10 August 1999 (Pakistan v. India), Jurisdiction,260 because, among other reasons, India had interposed a reservation to the instrument whereby it accepted the compulsory jurisdiction of the Court. ${ }^{261}$ In the course of reaching this conclusion, the court cited the practice of states in attaching such reservations to their declarations of acceptance of the compulsory jurisdiction as demonstrating the permissibility of such reservations. 262

However, the Court has not been consistent in its willingness to rely on the state practice of treaty parties as an element of treaty interpretation. In LaGrand (Germany $v$. United States), 263 it ignored state practice regarding the interpretation of its statute. The case was the result of the violation by the United States of its obligations to Germany under the Vienna Convention on Consular Relations ("Consular Convention").264 Specifically, Germany alleged and the United States conceded that state authorities in

\footnotetext{
257 Id. at 457 (citation omitted).

258 See id. at 458-63 (detailing the Spanish argument that a more restrictive interpretation of "conservation and management measures" should be adopted and the Canadian argument for a more expansive interpretation).

259 See id. at 461 (reviewing the usage of "conservation and management measures" and similar terms across a variety of international conventions and the domestic laws of Algeria, Argentina, the Malagasy Republic, New Zealand and the European Economic Community).

260 Aerial Incident of 10 August 1999 (Pak. v. India), 2000 I.C.J. 12 (June 21).

261 Id. at 25-32.

262 Id. at 30.

263 LaGrand (F.R.G. v. U.S.), 2001 I.C.J. 466 (June 27).

264 Vienna Convention on Consular Relations, Apr. 24, 1963, 21 U.S.T. 77, 596 U.N.T.S. 261[hereinafter Consular Convention].
} 
Arizona had failed to comply with the obligation under the Consular Convention 265 to inform two German nationals, the LaGrand brothers, of their right to consult the German consul after they were arrested for a 1982 murder.266 The LaGrands were convicted and sentenced to death in 1984. Upon learning of the treaty breach in 1992, they unsuccessfully sought relief in American courts, including the Supreme Court. Karl LaGrand was executed as scheduled on February 24, 1999. On March 2, 1999, Germany filed its application with the ICJ, requesting provisional measures, including an order to the effect that the United States "should take all measures at its disposal to ensure that Walter LaGrand was not executed" before the Court rendered judgment in the case, Walter's execution having been scheduled for March 3. The Court issued the order for provisional measures on March 3, and both Germany and Walter LaGrand sought relief from the United States Supreme Court on that day. Both were unsuccessful, and Walter LaGrand was executed on March 3, 1999.267

In its memorial, the United States argued on a number of grounds that provisional measures indicated by the Court imposed no binding legal obligation. 268 In particular, the United States argued that the practice of states respecting such orders demonstrates that the parties to the Court's statute do not read that treaty as imposing a legally binding obligation to carry out provisional measures. ${ }^{269}$ The Court, however, concluded that orders for provisional measures were indeed legally binding. 270 The court did not address all the American arguments, and did not so much as mention the American argument based on state

265 See id. art. 36, 596 U.N.T.S. at 292, 294 (calling for arresting countries to inform foreign nationals of their rights without delay).

266 See LaGrand, 2001 I.C.J. at 475 (recounting the charges against the LaGrand brothers at the time of their arrest). There was some dispute between the parties as to the time at which the relevant American authorities learned that the LaGrands were German nationals, but all agreed that the authorities were aware of this fact by late 1984. See id. at 475-76 (noting the initial confusion surrounding the nationality of the LaGrand brothers).

267 See id. at 475-79 (recounting the trial and appeals of the LaGrand brothers, the German involvement and the subsequent executions).

268 Counter-Memorial of the United States of America, LaGrand (F.R.G. v. U.S.) (Mar. 27, 2000), paras. 91, 138-65, available at http://www.icj-cij.org /docket/files/104/8554.pdf.

269 See id. paras. 161-64 (describing several instances where the I.C.J. found provisional and interim measures to be non-binding).

270 LaGrand, 2001 I.C.J. at 506. 
practice. $^{271}$

271 See id. at 501-06 (addressing the inconsistency between the English and French text of Article 41 and comparisons which might be made to illuminate the appropriate interpretation). Parts of the Court's analysis are surprising. A crucial element of the argument of the United States derived from the language of Article 41 of the Statute, which in its English version provides,

1. The Court shall have the power to indicate, if it considers that circumstances so require, any provisional measures which ought to be taken to preserve the respective rights of either party.

2. Pending the final decision, notice of the measures suggested shall forthwith be given to the parties and to the Security Council.

The equally authentic French version provides,

1. La Cour a le pouvoir d'indiquer, si elle estime que les circonstances l'exigent, quelles mesures conservatoires du droit de chacun doivent être prises à titre provisoire.

2. En attendant l'arrêt définitif, l'indication de ces mesures est immédiatement notifiée aux parties et au Conseil de sécurité ).

Id. at 501-02. The United States argued that the measures could not be characterized as obligatory since the terms used in the English text to describe the issuance of such measures, i.e., "indicate," "suggested," were not those lawyers would use to create an obligation. See Counter-Memorial of the United States of America, LaGrand, paras. 141-52 (detailing the United States argument regarding the English translation). The Court, however, characterized the word "devoir" (infinitive form of the word "doivent") as "having an imperative character," Lagrand, 2001 I.C.J. at 502. However, according to LAROUSSE, GRAND DICTIONAIRE FRANCAIS-ANGLAIS, ANGLAIS-FRANCAISE 274 (1993 ed.), while the first meaning of the verb "devoir," when translated into English, is "must," the second meaning is "should" or "ought." The Court purported to resolve what it saw as a difference in meaning between the English and French texts by resort to Article 33(4) of the Treaties Convention, supra note 16, which provides, "when a comparison of the authentic texts discloses a difference of meaning which the application of articles 31 and 32 does not remove, the meaning which best reconciles the texts, having regard to the object and purpose of the treaty, shall be adopted." Treaties Convention, supra note, art 31-32. Since "devoir" can mean "suggest," one might expect that the Court, seeking to "reconcile the texts" would accept that the two versions of Article 41 should in fact be seen as identical and that the Article should therefore be read as not creating a binding obligation. Instead, the Court made no effort to reconcile the texts, but leapt to a consideration of the "object and purpose" of the Statute, concluding on that basis that Article 41 created a binding obligation. Further, the Court's consideration of the preparatory work for Article 41 concluded:

The preparatory work of Article 41 shows that the preference given in the French text to "indiquer" over "ordonner" was motivated by the consideration that the Court did not have the means to assure the execution of its decisions. However, the lack of means of execution and the lack of binding force are two different matters. Hence, the fact that the Court does not itself have the means to ensure the execution of 
In four cases, the Court failed to give weight to the parties' interpretation of treaties other than its statute. One of these was LaGrand. The LaGrands had been denied habeas corpus relief in U.S. Federal court on the ground that, having failed to raise their Consular Convention argument in the earlier state proceedings, they had essentially waived the argument-the so-called rule of procedural default. In the ICJ case, Germany argued that application of the procedural default rule was a violation of Article 36.272 The United States asserted that the Article 36 claim was inadmissible in that Germany was seeking to hold the United States to a standard in the application of that provision stricter than that which it followed itself. ${ }^{273}$ Further, it asserted in its written pleadings that, based on investigations by American officials, "States Party to the Vienna Convention throughout the world operate on the understanding that a criminal proceeding against a foreign national can proceed regardless of whether consular notification is provided." 274

The Court rejected both arguments. As to the admissibility argument, the Court distinguished the German cases upon which the United States relied as entailing "relatively light criminal penalties" and as providing no evidence regarding German practice respecting criminal defendants facing severe penalties. Acknowledging that the Consular Convention draws no distinction in Article 36 between the severity of the penalties faced by arrested persons, the Court held that "it does not follow therefrom that the remedies for a violation of this Article must be identical in all situations." 275 The Court simply did not respond to the United States's argument regarding state practice with respect to the proper interpretation of Article 36; it rejected the United

orders made pursuant to Article 41 is not an argument against the binding nature of such orders.

LaGrand, 2001 I.C.J. at 505. In other words, since the Court disagreed with the reasons the drafters of the Statute gave for refraining from making Article 41 mandatory, it chooses to disregard clear evidence that, as far as the drafters were concerned, it was not mandatory.

272 Id. at 488.

273 Id. at $496-97$.

274 Counter-Memorial of the United States, LaGrand (F.R.G. v. U.S.), 2000 I.C.J, para. 91.

275 LaGrand, 2001 I.C.J. at 489. 
States's reading of that Article based solely on its exegesis of the language of the treaty. ${ }^{276}$

Avena and Other Mexican Nationals (Mexico v. United States of America), 277 another Consular Convention case, presented a similar situation. One element of Mexico's claim was that the Vienna Convention was properly interpreted as requiring the United States to inform foreign nationals of their Convention rights as soon as they were detained. ${ }^{278}$ As in LaGrand, the United States's argument against this position depended in part on a detailed examination of the practice of states in implementing Article 36.279 As it did with a similar American argument in LaGrand,280 the Court simply ignored the argument based on state practice in considering the issue, though it rejected Mexico's claim on other grounds. ${ }^{281}$ It only addressed this point obliquely, in the course of rejecting the American argument that Mexico's claim was inadmissible because it was seeking to impose on the United States a standard which its own behavior did not satisfy. ${ }^{282}$

The Wall Case presents a similar problem because of the Court's rejection of Israel's argument based on Article 51 of the Charter. Article 51 was irrelevant both because, according to the Court, Article 51 applies only to self-defense against attacks attributable to another state, which was not the case with respect to the attacks of which Israel complained, and because the attacks originated from areas under Israel's occupation. This latter point, again according to the Court, rendered irrelevant the Security Council resolutions condemning terrorism adopted in the wake of the attacks in the United States on September 11, 2001. In fact, those resolutions amount to state practice undercutting that conclusion. This is true because-although the preambles of both resolutions refer to "international peace and security" and/or "international terrorism," - both refer only to "terrorism" in their operative

\footnotetext{
276 Id. at 495-98.

277 Avena and Other Mexican Nationals (Mex. v. U.S.), 2004 I.C.J. 12 (Mar. 31).

278 Id. at 66-67.

279 Counter-Memorial for the United States, Avena and Other Mexican Nationals (Mex. v. U.S.) (U.S. Avena Counter-Memorial), 2004 I.C.J. 12, 89-98 (Mar. 31).

280 See supra text accompanying notes 263-67.

281 Avena and Other Mexican Nationals, 2004 I.C.J. at 67-68.

282 Id. at 61.
} 
paragraphs, 283 and because those resolutions were adopted in response to an attack which, from the beginning of the actual operation until its end, took place in the territory of the state attacked, as Professor Murphy has pointed out. ${ }^{284}$

DRC v. Uganda, 285 in holding that Article 51 did not permit Uganda to use force against anti-Uganda guerillas within DRC territory because the acts of those guerrillas could not be attributed to the DRC, 286 similarly failed to give weight to the post September 11 Security Council resolutions as relevant state practice.

\subsection{Summary}

The foregoing discussion makes clear that the Court's treatment of state practice has been quite inconsistent regarding both the determination of the content of CIL and the interpretation of treaties. To recapitulate the situation regarding CIL, the Court's activity can be broken down into 5 categories: 1) reliance on actual state practice as the source of CIL rules; 2) reliance on either secondary sources of law (judicial opinions or the writings of scholars) or non-binding instruments (e.g., General Assembly resolutions, actions of international conferences) as the source of rules, even though reliance on state practice would have produced the same result; 3) drawing CIL rules from secondary sources of law; 4) asserting the existence of rules of CIL without providing any basis for the assertion other than doubtful sources; 5) asserting

283 S.C. Res. 1368, U.N. Doc. S/RES/1368 (Sept. 12, 2001) (expressing sympathy for the U.S. after September 11 and agreeing to continue considering the issue of terrorism); S.C. Res. 1373, U.N. Doc. S/RES/1373 (Sept. 28, 2001) (condemning the use of terrorism and directing states to stop funding or supporting terrorist organizations and work together to prevent further attacks).

284 Murphy, supra note 10, at 68 (discussing the seemingly arbitrary factual distinction the ICJ draws between the September 11, 2001 attacks in the United States - a result of a threat the ICJ says originated outside U.S. territory - and the attacks in Israeli territory, that the ICJ says were entirely domestic). It is also worth noting that the Court's conclusion that Article 51 applies only to defense against attacks imputable to a state has no support in the text of the article, as Judge Koojimans noted in his separate opinion in the Wall Case. Legal Consequences of the Construction of a Wall in Occupied Palestinian Territory 2004 I.C.J. 136, 1072 (July 9) (Koojimans, J. sep. opin.). Professor Murphy has also pointed out that the classic statement of the parameters of the right of self-defense was formulated in the context of an action not attributable to a state. Murphy, supra note 10 , at 64-65.

285 Armed Activities on the Territory of the Congo (Dem. Rep. Congo v. Uganda), 45 I.L.M. 271 (Dec. 19, 2005).

286 Id. at 306. 
the existence of rules of CIL drawn from secondary sources and non-binding instruments when the asserted rules are actually contradicted by significant state practice. With respect to treaties, the Court has invoked the rule that treaties are to be interpreted in light of the practice of the treaty parties and has followed this rule in some cases. In others, however, it did not follow the rule; in those cases, furthermore, it did not acknowledge the existence either of the rule or of the practice of the treaty parties. In none of these cases did the Court explain its choice to proceed in one way or another or offer any legal rationale for its different methods of analysis.

The next section turns to an analysis of the Court's performance.

\section{WhAT THE COURT SEEMS TO BE DOING, AND WHY WE SHOULD CARE}

\subsection{What the Court is Doing}

The preceding discussion addressed 27 cases, each offering the Court the opportunity to ground its analysis of the relevant law in the practice of states, either because the case presented issues of CIL or because the case involved a treaty interpretation issue, which could have been addressed by considering the practice under the treaty of the treaty parties. Examination of these cases makes it possible to see some patterns of arguably problematic behavior in the Court's proceedings. This Section of the Article seeks to identify those patterns. The following Section addresses their legal implications.

One may, roughly, divide the patterns the cases present into two groups: those involving the actions and institutions the Court treats as being sources of rules of law, and those involving the analytical techniques the Court brings to bear in its consideration of these sources. In treaty cases, the source of the parties' obligations will be uncontroversial-it would be whatever the relevant treaty was. Therefore, the sources question can arise only in cases involving CIL. The issue of analytical techniques, however, can arise either in CIL cases or in treaty interpretation cases, since, obviously, both present problems of analysis.

\subsubsection{Sources of law}


The first source of law to consider is state practice, as defined above.287 Surprisingly, the Court seems to have paid relatively little attention to this source of law. Only in the Nuclear Weapons Case $^{288}$ did the result turn on the actual practice of states (in that case, nuclear deterrence). The Court did not describe that practice, referring only to "the policy of deterrence." Since the nature of the policy was well-known and, at the time of the decision, only the five permanent members of the Security Council admitted to possessing nuclear weapons ${ }^{289}$ the Court's bare reference to the practice was arguably adequate both to describe the sort of activity in which states were engaging and to indicate which states were acting. The Court's description of the practice on which it relied nonetheless seems remarkably terse.

In the other cases in which the Court made reference to state practice, its description of that practice was even less specific. In the Continental Shelf Case, ${ }^{290}$ the Court cited the practice of states in holding that the institution of the Exclusive Economic Zone had passed into CIL, among other holdings, but did not describe the practice, or even indicate the number of states involved.291 It further held that use of one particular method of delimitation of the continental shelf was shown to be acceptable, albeit not mandatory, by the seventy agreements between states delimiting their shelves.292 While the Court at least indicated the number of instances of practices at issue on this point, it provided no further information.

In the other two cases in which the Court purported to rely on state practice to determine the content of CIL, its treatment of CIL was even less explicit. In DRC v. Belgium, 293 the Court's description of the state practice on which it relied was non-existent in one part

287 See discussion, supra Section 2.1.1.

$8)$.

288 Threat or Use of Nuclear Weapons, Advisory Opinion, 1996 I.C.J. 226 (July

289 It was only in 1996 that India and Pakistan admitted to acquiring those weapons. See, e.g., Barbara Crossette, South Asian Arms Race: Reviving Dormant Fears of Nuclear War, N.Y. TIMES, May 29, 1998, at A9.

290 Continental Shelf (Libya v. Malta), 1985 I.C.J. 13 (July 3).

291 Id. at 33, 38.

292 Id. at 38.

293 Arrest Warrant of 11 April 2000 (Dem. Rep. Congo v. Belg.), 2002 I.C.J. 3 (Feb. 14). 
of the opinion, and sketchy in the other. ${ }^{294}$ In the Diallo Case, ${ }^{295}$ the Court described the practice on which the applicant relied, but provided very little explanation for its conclusion that the practice did not show the existence of a CIL rule. ${ }^{296}$

In the foregoing cases, the Court at least purported to rely on state practice to establish a CIL rule. In the remaining CIL cases, however, the Court failed to address state practice. This was most surprising in those cases where state practice would have strongly supported the result the Court reached.297 In the Gulf of Maine, 298 Continental Shelf,299 and Denmark v. Norway ${ }^{300}$ judgments, the Court made no express mention of the very large numbers of states claiming exclusive economic zones, though that practice would have supported its purported CIL result. In Hungary v. Slovakia301 and the Special Rapporteur Advisory Opinion, 302 the Court chose to rely on the conclusions the ILC had reached regarding certain rules of CIL, rather than on the practice, which had been carefully described by the ILC, on which those conclusions were based. And in the other CIL cases discussed, the Court either made no reference to state practice, or ignored or mischaracterized practice contrary to the result it reached. While some of these cases were conventional border disputes, lending themselves to resolution through reliance on subsidiary sources of law, others were not. 303

294 Id. at 20-22, 23-24 (discussing "state practice" and "international custom" surrounding immunities of Ministers of Foreign Affairs and how the immunity applies to allegations of certain crimes such as war crimes or crimes against humanity with only minimal references to examples of actual international practice).

295 Ahmadou Sadio Diallo (Guinea v. Congo), May 24, 2007, 46 I.L.M. 712.

296 Id. paras. 89-90 (concluding that some international agreements, provisions in many contracts and certain special cases were not sufficient evidence of customary international law).

297 See supra text accompanying notes 52-80.

298 Delimitation of the Maritime Boundary in the Gulf of Maine Area (Can. v. U.S.), 1984 I.C.J. 246 (Oct. 12) (Gulf of Maine Case).

299 Continental Shelf (Libya v. Malta), 1985 I.C.J. 13 (June 3) (Continental Shelf Case).

300 Maritime Delimitation in the Area between Greenland and Jan Mayen (Den. v. Nor.), 1993 I.C.J. 38 (June 14) (Denmark v. Norway).

301 Gabčíkovo-Nagymaros Project (Hung. v. Slovk.), 1997 I.C.J. 7 (Sept. 25) (Hungary v. Slovakia).

302 Difference Relating to Immunity from Legal Process of a Special Rapporteur of the Commission on Human Rights, Advisory Opinion, 1999 I.C.J. 62 (Apr. 29) (Special Rapporteur Advisory Opinion).

303 See supra text accompanying notes 81-233. 
These results, it should be stressed, cannot be explained as flowing from some difficulty the Court has encountered in recent decades in determining the content of state practice. Its careful discussion of practice in interpreting the treaty at issue in Spain $v$. Canada ${ }^{304}$ shows that, when it chose to do so, the Court was capable of subjecting practice to very thorough examination.

It is clear then that what the Court has not been doing in CIL cases is basing its judgments on carefully described state practice. What is has been doing instead is also significant: it has been relying on international bodies, the governing legal instruments of which confer on them no authority to create general obligations in international law. More precisely, the Court has relied, 1) on actions by the General Assembly and by states meeting in international conferences; 2) on determinations by bodies composed of individual experts; and 3) on its own precedents and policy determinations. Each of these categories requires some comment.

The Court expressly relied on General Assembly resolutions to support its results in Nicaragua, Merits, 305 in the Nuclear Weapons Case, 306 in the Wall Case, 307 and in DRC v. Uganda. ${ }^{308}$ Indeed, in Hungary v. Slovakia, 309 the Court even relied on the General Assembly's adoption of a treaty text as establishing the treaty's provisions as $\mathrm{CIL}, 310$ even though the treaty in question was not then in force, and in fact has never come into force. ${ }^{311}$

304 Fisheries Jurisdiction (Spain v. Can.), 1998 I.C.J. 432, 461 (Dec. 4) (Spain v. Canada) (tracking the meaning of the term "conservation and management measures" from the UN Convention on the Law of the Sea and a variety of other treaties and conventions amongst many European and North American countries).

305 Military and Paramilitary Activities (Nicar. v. U.S.), 1986 I.C.J. 14 (June 27) (Nicaragua, Merits).

306 Legality of the Threat or Use of Nuclear Weapons, Advisory Opinion, 1996 I.C.J. 226, 242-43 (July 8) (Nuclear Weapons Case).

307 Legal Consequences of the Construction of a Wall in the Occupied Palestinian Territory, Advisory Opinion, 2004 I.C.J. 136, 171-72, 176 (July 9) (Wall Case).

308 Armed Activities on the Territory of the Congo (Dem. Rep. Congo v. Uganda), 45 I.L.M. 271, 308-09, Dec. 19, 2005 (DRC v. Uganda).

309 Gabčíkovo-Nagymaros Project (Hung. v. Slovk.), 1997 I.C.J. 7 (Sept. 25)

(Hungary v. Slovakia).

310 Id. at 56.

311 See, International Water Law Project, Status of the Convention, http://www.internationalwaterlaw.org/documents/intldocs/watercourse_status 
The Court based its judgment on the work of international conferences in a number of cases. The Court relied on the work of the Third United Nations Conference on the Law of the Sea-even as it acknowledged that the treaty the Conference had produced had not yet gone into force-in the Gulf of Maine Case, 312 the Continental Shelf Case, 313 and Denmark v. Norway. ${ }^{314}$ Similarly, in Nicaragua, Merits, the Court characterized the acceptance by the United States of certain non-binding resolutions at international conferences as demonstrating opinio juris regarding a principle of CIL.

The Court, as noted above, also relied on the work of certain expert bodies, such as the ILC 315 and the Human Rights Committee,, 316 as sources for rules of law. Certainly, the individuals who compose such bodies would count as falling among those "highly qualified publicists" whose work the Statute of the Court describes as subsidiary means for determining the content of international law. In that sense, there is more basis for reliance on their pronouncements than for reliance on actions by the General Assembly or international conferences. Even here, however, the Court's approach has been curious. It does not appear to have treated the work of such bodies as subsidiary means of determining the content of international law, but rather as having the same force as other sources mentioned in Article 38. For example, in the Special Rapporteur Advisory Opinion, 317 the Court referred to the ILC's draft Articles on State responsibility, ${ }^{318}$ but not to the state practice on which those articles were based and which

.html (last visited Dec, 3, 2009) (tracking the very limited number of states that have signed and ratified the Watercourse Convention, as of Nov. 28, 2009).

312 Delimitation of the Maritime Boundary in the Gulf of Maine Area (Can. v. U.S.), 1984 I.C.J. 246, 294 (Oct. 12) (Gulf of Maine Case).

313 Continental Shelf (Libya v. Malta) 1985 I.C.J. 13, 40-41 (June 3).

314 Maritime Delimitation in the Area between Greenland and Jan Mayen (Den. v. Nor.), 1993 I.C.J. 38, 62 (June 14) (Denmark v. Norway).

315 See Gabčíkovo -Nagymaros Project (Hung. v. Slovk.), 1997 I.C.J. 7, 72

(Sept. 25) (Hungary v. Slovakia); Difference Relating to Immunity from Legal Process of a Special Rapporteur of the Commission on Human Rights, Advisory Opinion, 1999 I.C.J. 62, 87 (Apr. 29) (Special Rapporteur Advisory Opinion).

316 Legal Consequences of the Construction of a Wall in the Occupied Palestinian Territory, 2004 I.C.J. 136, 179 (July 9) (Wall Case).

317 Special Rapporteur Advisory Opinion, 1999 I.C.J. at 87.

318 Id. at 87. 
was described in the ILC's commentary to its draft. ${ }^{319}$ Yet if the works of publicists are subsidiary to state practice, one would expect the court to rely on the primary rather than on the subsidiary source, especially when the primary source was easily available.320 A particularly striking example of the Court's attempts to justify reliance on expert bodies is presented by the Court's justification, in the Wall Case, for citing a declaration by the ICRC interpreting the Fourth Geneva Convention. The Court quoted an article of that treaty apparently to support the argument that the Committee's treaty interpretations were authoritative; ${ }^{321}$ however, read in context, the article clearly refers to other issues entirely. 322

Finally, the Court has relied on its own decisions as authority supporting particular propositions of law. Now, in one sense, this cannot be surprising. If the Court has examined a legal issue once, it would be a waste of time for the Court to exhaustively re-analyze the issue in future cases, all things being equal. The difficulty arises in cases where all things are not equal, that is, when there have been legally relevant developments subsequent to a decision by the Court which could, at least, require a result different from that the Court originally reached. For example, as discussed above, 323 the Court in the Genocide Casefollowed Nicaragua, Merits in its approach to determining whether a government was responsible for the acts of armed groups. ${ }^{324}$ It referred to no authority besides its own decision and that of the ICTY in the Tadic Case $^{325}$ in addressing the issue. Yet there had, during the period between the two decisions, been a number of incidents of state

319 Int'l Law Comm'n, Report of the International Law Commission on the Work of Its Twenty-fifth Session 7 May-13 July, 1973, at 36, U.N. Doc. A/9010/REV.1 (1973), reprinted in 2 Y.B. INT'L COMM'N 1983, U.N. Doc. A/CN.4/SER.A/1973.

320 Ahmadou Sadio Diallo (Guinea v. Congo), May 24, 2007, 46 I.L.M. 712, para. 39. The Court relied on an ILC draft for a definition of the term "diplomatic protection" - a definition so uncontroversial as, arguably, requiring no supporting authority at all.

321 Wall Case, 2004 I.C.J. at 176.

322 See Fourth Geneva Convention, supra note 176, art. 142.

323 See supra text accompanying notes 173-90.

324 Application of the Convention on the Prevention and Punishment of the Crime of Genocide (Bosn. \& Herz. v. Serb. \& Mont.), 2007 I.C.J. 188, 248 (Feb. 26) (Genocide Case).

325 Prosecutor v. Tadić, Case No. IT-94-1-A, Appeals Chamber Judgment, (July 15, 1999). 
practice arguably relevant to the issue.326 Since the issue was one of CIL, it would seem that the Court could have been expected to examine these instances of practice subsequent to Nicaragua, Merits to assure itself that this more recent practice did not require modification of the views it had expressed in that case. It did not do so, however-in essence treating its decision and that of the ICTY as the only sources of law it needed to consider.

In addition to relying on its own decisions as precedent, the Court has also explicitly justified results on the basis of its own, independent policy analysis. In DRC v. Belgium, ${ }^{327}$ the basis for the Court's decision was its conclusion regarding the policy difficulties which it asserted would be created if Belgium were to be allowed to go ahead with its criminal proceedings.328 Similarly, in the Genocide Case, the Court rejected the attribution standard urged by Bosnia-Herzegovina because of what the Court saw as the practical difficulties that standard would create. ${ }^{329}$

\subsubsection{Analytical Technique}

The foregoing discussion addressed arguably problematic approaches to sources of law the Court has employed over the period under examination. This portion of the discussion focuses on the methods of analysis that seem to raise questions.

The first of these analytical problems is the lack of transparency in the Court's opinions. In a surprising number of cases, the Court has asserted the existence of a particular rule of law without explaining how it has come to conclude that the rule is a rule, even though the existence of the rule is by no means uncontroversial. There are a number of examples.

In the Gulf of Maine Case, the Court based its analysis of CIL in part on actions taken at the Third United Nations Conference on the Law of the Sea, rather than on the practice of a very large number of states; while the Court stressed the degree of consensus at the Conference and the acceptance of the principle in question by the United States, despite overall American objections to UNCLOS, it did not explain why these elements created a rule of

326 See Christine Gray, InTERnATIONAL LAW AND THE USE OF FORCE 161-67 (2d ed. 2004). (Discussing arguably relevant incidents).

327 Arrest Warrant of 11 April 2000 (Dem. Rep. Congo v. Belg.), 2002 I.C.J. 3

(Feb. 14) (DRC v. Belgium).

328 Id. at 20-22.

329 Genocide Case, 2007 I.C.J. at 286-88. 
law. In the Continental Shelf Case and later in Denmark v. Norway, the Court simply repeated its conclusions from the Gulf of Maine Case, ignoring extensive state practice supporting its result and again failing to explain why it did not rest its judgment on what presumably would have been the strongest available foundation.

The Court stated in Nicaragua, Merits, 330 with respect to CIL rules which states had violated, that:

If a State acts in a way prima facie incompatible with a recognized rule, but defends its conduct by appealing to exceptions or justifications contained within the rule itself, then whether or not the State's conduct is in fact justifiable on that basis, the significance of that attitude is to confirm rather than to weaken the rule. 331

The Court simply asserted this conclusion without explaining the reasoning behind it. In the same case, in a purported effort to determine whether there was opinio juris supporting the argument that the Charter's use of force rules had become part of CIL, the Court treated the Declaration on Friendly Relations ${ }^{332}$ as evidence of that opinio juris, asserting that "[t]he effect of consent to the text of such resolutions cannot be understood as merely that of a 'reiteration or elucidation' of the treaty commitment undertaken in the Charter," but "may be understood as an acceptance of the validity of the rule or set of rules declared by the resolution by themselves." 333 The Court did not explain why this should be so. It likewise did not explain its rationale for labeling as a demonstration of opinio juris for this principle the acceptance by the United States of non-binding resolutions at two international conferences and its ratification of a treaty. Also in this case, the Court simply announced the standard it applied to determine whether the acts of the Nicaraguan contras could be attributed to the United States without explaining the derivation of this standard. As described above, ${ }^{334}$ the ICJ dealt with a similar issue in the same way in the Genocide Case, supporting its conclusion 27).

330 Military and Paramilitary Activities (Nicar. v. U.S.), 1986 I.C.J. 14 (June

331 Id. at 98 .

332 Declaration on Friendly Relations, supra note 133.

333 Military and Paramilitary Activities, 1986 I.C.J. at 99-100.

334 See supra text accompanying notes 191-94 (discussing in more detail the nature of the Genocide Case). 
regarding attribution only by reference to another unexplained conclusion regarding the consequences of using a standard different from the one it had selected. This latter point is particularly striking in light of the ICTY opinion to which the Court in the Genocide Case was responding; the ICTY's opinion was carefully reasoned, while that of the ICJ rested simply on assertion.

In the Oil Platforms Case, as noted above, 335 the Court in effect asserted that 1) a state is the victim of an armed attack only if the attack is directed specifically at it; indiscriminate attacks do not count; 2) an armed action by the armed forces of one state against those of another is not necessarily an armed attack; whether it is depends on its gravity; 3) an action taken in self-defense cannot satisfy the necessity requirement unless it is preceded by a formal complaint by the ostensibly defending state, however pointless the making of such a complaint might be; and 4) the proportionality criterion in the law of self-defense is evaluated in terms of the harm already inflicted, not that to be avoided. The Court provided no authority for any of these propositions, nor did it otherwise explain their derivation.

In the Wall Case, 336 the Court asserted, without explanation, that a state could not assert the right of self-defense to justify using force against a territory under Article 51 of the Charter if the danger against which the state wished to act was not created by another state, 337 even though Article 51 sets out no such limitation. It took a similar position, with a similar lack of explanation, in DRC v. Uganda. 338

In addition to its failure to explain the basis for the rules it has applied, the Court, in some cases, has adopted methods of analysis inconsistent with those used in other cases, but has made no reference to the arguments it fails to address, an omission which has the effect of concealing the inconsistency. Obviously, if the Court does not acknowledge a departure from previous analytical practice, it does not explain the legal rationale for the departure. This problem appears in LaGrand, with respect to both the American argument regarding the binding character of provisional

335 See supra text accompanying notes 155-65.

336 Legal Consequences of the Construction of a Wall in the Occupied Palestinian Territory, 2004 I.C.J. 136 (July 9) (Wall Case).

337 Id. at 194.

338 Armed Activities on the Territory of the Congo (Dem. Rep. Congo v. Uganda), Dec. 19. 2005, 45 I.L.M. 271 (DRC v. Uganda). 
measures under Article 41,339 and the American argument as to the proper interpretation of Article 36 of the Consular Convention. ${ }^{340}$ In both instances, the United States asserted an interpretation of a treaty based on the practice of the parties to the treaty with respect to the provision in question. Despite its frequent holdings that such practice was to be considered in cases of treaty interpretation, the Court not only failed to consider the practice, but failed to acknowledge that the practice existed. Similarly, in Avena, although the United States based its disagreement with the Mexican interpretation of Article 36 of the Consular Convention in part on the practice of the parties to that treaty, the Court did not even acknowledge that the argument had been made. 341 Similarly, in the Diallo Case, the Court relied on the ILC's Draft Articles on Diplomatic Protection for some aspects of its judgment, but did not address the fact that the ILC had, in the commentaries to those articles, reached a conclusion contrary to that reached by the Court regarding another issue in the case. ${ }^{342}$ Further, in addressing that issue, the Court took note of arguments raised by Guinea, but failed to mention that one of the authorities upon which Guinea relied was the ILC. 343

Finally, in Nicaragua, Merits, it flatly misstated state practice. It did this when it rationalized its refusal to put weight on states' interventions in the internal affairs of other states in part by asserting that intervening states never offered legal justifications for their actions. ${ }^{344}$ In fact, as discussed above, ${ }^{345}$ in several notable instances, intervening states had made explicit both their beliefs

339 Compare Counter-Memorial of the United States, LaGrand (F.R.G. v. U.S.), 2000 I.C.J. paras. 91, 138-65 (Mar. 27), with LaGrand, (F.R.G. v. U.S.), 2001 I.C.J. 499, 501-06 (June 27).

340 Compare Counter-Memorial of the United States., LaGrand, 2000 I.C.J. at para. 91, with LaGrand, 2001 I.C.J. at 495-98.

341 Compare Counter-Memorial for the United States, Avena and Other Mexican Nationals (Mex. v. U.S.), 2004 I.C.J. 12 (Nov. 3), 89-98, paras. 6.32-6.43 (Mar. 31), with Avena and Other Mexican Nationals (Mex. v. U.S.), 2004 I.C.J. 12, 67-68 (Mar. 31).

342 Compare Diplomatic Protection Draft Articles, supra note 243, at 62-65, with Diallo Case (Guinea v. Congo), Preliminary Objections, 2007 I.C.J. 1, 29-31.

343 See Preliminary Objections, Ahmadou Sadio Diallo (Guinea v. Dem. Rep. Congo) 46 I.L.M. 712 (Diallo Case).

344 Military and Paramilitary Activities (Nicar. v. U.S.), 1986 I.C.J. 14, 108-10 (June 27).

345 See supra note 224 (explaining various states' interventions in other countries and their justifications for intervening). 
that their actions were justified and the legal arguments supporting those conclusions.

\subsection{Why We Should Care About the Court's Approach}

\subsubsection{Introduction}

We see then that, over the period in question, the Court has generally dealt with state practice in a fairly summary fashion; relied, as sources of legal rules, on entities whose legal authority is doubtful; frequently failed to explain the derivation of the rules upon which it relies; failed sometimes even to mention arguably plausible counter-arguments raised either by the parties or by authorities upon which the Court purported to rely and, once, flatly misstated the content of state practice.

Beyond the foregoing observations, however, it is important to note two important implications of these patterns of behavior on the part of the Court. First, it appears to be attempting to shift the authority to make international law from states to non-state international bodies. States make law through their practice and through concluding and subsequently applying treaties. If the Court gives little attention to state practice, and, in at least some cases, disregards clear indications of the parties' understanding of otherwise ambiguous treaty language, the Court is effectively limiting the law-making role of states. Conversely, it is necessarily magnifying the role of other international bodies if it ascribes binding legal effect to General Assembly resolutions, to the determinations of international conferences, to groups of experts in international law, and to its own earlier decisions.

The second implication of the patterns of the Court's behavior is that it seems to be moving away from what could be reasonably called a judicial role to that of a free-form policy maker. One normally expects a tribunal to explain the reasoning from which it derives the legal rules it applies, but the ICJ has, as described, failed to do so on a number of occasions. One also expects courts to provide guidance to the community by explaining the flaws in the legal arguments it rejects, which necessarily requires the court to note that the argument has been made. To fail even to acknowledge that a party has made a particular argument makes it impossible for the parties and the international community generally to understand the legal basis for disregarding the 
argument-and necessarily feeds the suspicion that the argument was ignored, not because it was incorrect, but because it was both correct and inconsistent with the result the Court wished to reach. Naturally, if the Court misstates the facts, these suspicions can only be reinforced.

This section examines the difficulties these practices raise.

\subsubsection{Sources of law}

The question of the sources from which the Court draws what it labels rules of CIL can seem a drily technical one. It is more than that. CIL purports to govern the behavior of all states; treaties, however, govern only the behavior of treaty parties. Therefore, authority to make CIL amounts to authority to control the actions of every state in the world. Since states are the mechanisms through which their populations interact, controlling all states means controlling all people. Explaining how it happens that this or that source of CIL may come to have so far-reaching an effect goes beyond mere technicality. Rather, such an explanation is at the heart of political legitimacy.

It is easy enough to justify reliance on state practice as a source of the CIL the Court applies. In the first place, the Court is constrained to rely on state practice by its statute. Beyond that point, states have a considerable claim to be speaking for their populations, and, to the extent that they do, it is simply an exercise of that authority when they create obligations for themselves that impact their populations. Further, states are the institutions far and away best able to ensure that CIL rules actually govern international relations, since states have a great deal of control of the resources of their populations, and thus have a broad range of means for giving practical effect to their decisions.

As discussed above, however, the Court in recent decades has, to a great extent, shifted its focus with respect to CIL away from states, looking instead to resolutions of the General Assembly, to actions by international conferences (as opposed to considering the legal effect of any treaties those conferences may produce), to determinations by expert bodies, and to its own decisions. For the Court to treat such materials as sources of law raises a number of problems. 
In the first place, as Reisman has observed, Article 38 of the Statute of the Court is a choice of law clause. ${ }^{346}$ Its terms are mandatory. Even if it could somehow be argued that international law has seen the emergence of new sources of law since 1945, Article 38 represents the unequivocal determination of the states whose governments accepted the statute that the Court would be permitted to rely solely on the sources listed in Article 38 to produce the rules of law which it applies.

This might seem like a mindlessly formalistic approach. There are at least two arguments against that objection. First, the basic question raised by any person or group purporting to exercise legal authority is, why should anyone feel obliged to pay any attention to what these people say? Why are the judges of the Court anything more than fifteen people wearing robes? The answer, surely, is that they are authorized to exercise the powers they exercise. If, however, that is the answer, then to the extent that the judges seek to exercise powers beyond those authorized, they are simply fifteen people wearing robes. And for the Court to apply sources of law not listed in Article 38 is for it to do just that and to go beyond its authority.

The second argument against this stress on the language of Article 38 flows from an analogy to the federal courts in the United States. At the time of the drafting of the Constitution, one concern about the establishment of a federal government was the fear that such a government must necessarily become a tyranny. The federal courts' rigid enforcement of limits on their jurisdiction reflected the triumph of the idea that, as the possessor of one aspect of federal power, it was as necessary for the courts as for the other branches of the federal government to respect the Constitution's limits on that power. ${ }^{347}$ Any other approach, it was thought, would weaken the fabric of the country.

The Court's position is, if anything, more precarious than that of the federal courts in the early days of the United States. Lacking either compulsory jurisdiction or, as a practical matter, any means

346 W. MichaEl REISMAN, SYSTEMS OF CONTROL IN INTERNATIONAL ADJUDICATIONS AND ARBITRATION: BREAKDOWN AND REPAIR (1992).

347 See Stewart Jay, Origins of Federal Common Law: Part One, 133 U. PA. L. Rev. $1003,1033,1111-13$ (1985) (summarizing the political history behind the issue of defining the boundaries of federal common law); Stewart Jay, Origins of Federal Common Law: Part Two, 133 U. PA. L. REV. 1231, 1241-42 (1985) (discussing development of a separation-of-powers principle that limits the jurisdiction of the federal court system in the United States). 
of enforcing its judgments, its effectiveness depends entirely on the states' willingness to accept those judgments. For the Court to depart from the terms of the Statute which specify the sources it may treat as giving rise to law, therefore, is to risk defiance.

The foregoing point addresses the extent of the Court's discretion to look to sources of law other than those the Statute identifies, or to treat certain sources which the Statute designates as subsidiary means for the determination of law as though they were primary sources of law. But even if the issue were the propriety of some institution not constrained by Article 38 to rely on the sources the Court has come to emphasize, one must still determine how it is that those sources can be considered law.

The most basic question goes to formal authorization. Consider first the General Assembly. According to the Charter of the United Nations, the General Assembly's authority to take actions regarding matters other than the internal functioning of the organizations extends no further than the power to make recommendations, albeit regarding a broad variety of subjects. 348 As Professor Thirlway has observed:

[T] he question of the effects of an Assembly resolution and that of the significance of the voting can become entangled in a sort of vicious circle: as the representative of Russia reminded the Court [during the argument on the Nuclear Weapons Case]: 'Many States prefer rather to vote in favour of these resolutions or abstain from voting, than to vote against them, having precisely in mind that, according to the Charter, they do not create any legal norm and do not imply the recognition of any rules as such, but are only of recommendatory nature .... The point is that, for each individual State participating in the voting, its vote is not directed to a particular dispute or situation affecting it, but is merely a general announcement of what it might contend if such a dispute or situation arose. Furthermore, if it were an established principle that voting for a purportedly declaratory resolution constituted acceptance of the rule therein stated, then to vote in this way would have an immediate impact on the legal position of the voting State; but so long as there exists no such principle, the vote by

348 U.N. Charter arts. 10-14. 
each State is legally insignificant because it is known (and intended) to be insignificant. 349

There is a further problem beyond that presented by the knowledge of states and their representatives that General Assembly resolutions have no legal effect-one of logic. For example, in the Nuclear Weapons Case, the Court noted that "General Assembly resolutions, even if they are not binding, may sometimes have normative value. They can, in certain circumstances, provide evidence important for establishing the existence of a rule or the emergence of an opinio juris." 350 However, a vote for a resolution can indicate opinio juris only if it commits the voting state to the proposition that whatever rule the resolution asserts is legally binding. But if the vote is non-binding, it is unclear how it can commit the state to anything.

The Court's effective ascription of formal authority to international conferences is at least as difficult to justify as its giving controlling weight to General Assembly resolutions. Just as the U.N. Charter accords no legal effect to General Assembly resolutions, actions at conferences in themselves have no legal effect. To be sure, a conference may produce a treaty; it may also demonstrate the existence of an apparent consensus on some subject which leads states to take specific actions regarding concrete issues. However, until there is reason to see the actions of a conference as having affected some issue outside the conference hall, there seems to be no basis for ascribing any legal consequences to the mere fact that a conference met and, perhaps, took non-binding stands on this or that issue. After all, states may find even a treaty produced by a conference unacceptable despite their representatives having agreed on a text. 351

349 Hugh Thirlway, The Law and Procedure of the International Court of Justice 1960-1989, 76 BRIT. Y.B. INT'L L. 1, 99-100 (2006) (quoting Verbatim Record, Legality of the Use by a State of Nuclear Weapons in Armed Conflict and Legality of the Threat or Use of Nuclear Weapons, Advisory Opinion (Nov. 10, 1995), available at http:/ / www.icj-cij.org/docket/files/93/5964.pdf).

350 Legality of the Threat or Use of Nuclear Weapons, Advisory Opinion, 1996 I.C.J. 226, 254-55 (July 8) (italics in original).

351 For example, even though the Vienna Convention on the Law of Treaties Between States and International Organizations or Between International Organizations was adopted by the General Assembly in Decision 41/420, it has not yet become effective. See United Nations Treaty Collection, Status of Vienna Convention on the Law of Treaties between States and International Organizations or between International Organizations, http://treaties.un.org 
The situation of expert bodies as sources of law is somewhat different from that of the General Assembly or of a conference. As already noted, the work of bodies such as the ILC can fairly be considered subsidiary means for the determination of international law within the meaning of article $38(1)(d)$. However, the Court cites the work of such bodies even when information on primary sources is available, for example, the ILC's own reports on state practice regarding the subjects it addresses. The implication is that the Court's focus is not on the actions of states, but on the determinations of the body of experts. This would seem justifiable only if the instruments establishing these bodies invest them with the power to make CIL. ${ }^{352}$ Those instruments contain no such provision. For example, nothing in the Statute of the ILC gives it the authority to make law; it is authorized to propose actions to states, not to change the law by its own action. ${ }^{353}$

Similarly, the Court's reliance on its own decisions cannot be based on any grant of authority. On the contrary, Article 59 of the Statute provides that the Court's decisions have no binding force, except between the parties and with respect to the particular case. And Article 38(1)(d) makes explicit that the Court's authority to treat judicial decisions as subsidiary means for the determination of rules of law is subject to Article 59.354 Again, this is not to say that, when the Court has thoroughly examined a particular CIL issue in one case, it must always repeat the discussion in later cases even if nothing has happened since the first decision which could be thought to change the legal rule. It is rather to say that, when the Court's citation to an earlier case is anything more than a "see discussion at" reference, it appears to violate the express language of its Statute.

Judge Shahabuddeen has attempted to defend the Court's reliance on its own case law, but his arguments are flawed.

/Pages/ViewDetails.aspx?src=TREATY\&mtdsg_no=XXIII-3\&chapter=23\&lang =en (last visited Dec. 3, 2009).

352 See, e.g., Report of the International Law Commission on the Work of Its Fortyninth Session, 12 May-18 July 1997, supra note 185, at paras. 76, 85-87, 134, available at http://untreaty.un.org/ilc/documentation/english/A_52_10.pdf (referencing the scope of authority of committees established to monitor compliance with human rights treaties).

353 See Statute of the International Law Commission, G.A. Res. 174 (II), U.N. Doc. A/519, arts. 15-24, (Nov. 21, 1947) (refraining from granting the ICJ the authority to make law).

354 I.C.J. Statute, supra note 2, arts. 38(1)(d), 59. 
Essentially, he argues that the Court's treating its own decisions as sources of law is inherent in its nature as a permanently established court. ${ }^{355}$ Acknowledging that, with respect to domestic courts, the exercise of such power flows from the possession by those courts of some elements of the overall sovereignty of the state of whose government they form a part, he has asserted that the states of the world have delegated to the Court the authority to make law. ${ }^{356}$ The short answer to all these arguments is that, as the creators of the Court, the states forming it presumably could limit its powers as they chose, and that they have expressed those limits in the terms of the Statute. The strict limits the Statute imposes on the Court's powers cannot be reconciled with some notion that the Court was nonetheless intended to exercise the authority it has claimed. Beyond these points, one element of Judge Shahabuddeen's discussion appears to contradict his conclusion. He observes that "[n]ew cases sometimes influence the development of state practice." 357 But, if decisions only sometimes influence practice, it follows that, on other occasions, decisions do not influence practice. If states ignore the Court's decisions in their practice, it would appear that a subsidiary means for the determination of law, that is, the Court's case law, is in conflict with a primary source of law, that is, state practice. In such a case, for the Court to rely on an earlier decision in later cases, notwithstanding the states' failure to conform their practice to that decision, would appear to give a subsidiary source of law priority over a primary source. That result seems difficult to justify.

To this point, this Section has argued that reliance on state practice as a source of CIL can be justified, both as required by the Statute and as consistent with the states' capacity to represent their populations and their control of very significant resources. In contrast, the Court's treating General Assembly resolutions, the actions of conferences, determinations by expert bodies and its own decisions as sources of law is not consistent with its Statute and, further, accords such institutions power they are not granted by their founding instruments. Beyond these points, however, there is another-why does it make sense to treat particular behaviors as sources of law? In other words, according to what

\footnotetext{
355 Mohamed ShahabuddeEn, Precedent in the World Court 40-41 (1996).

356 Id. at 93.

357 Id. at 209.
} 
legal theory is it reasonable to treat institutions generating normative statements, i.e., statements of the form " $X$ is forbidden," " $\mathrm{Y}$ is optional," " $\mathrm{Z}$ is mandatory," as creating law as opposed to creating, for example, rules of games, or moral propositions, or political positions?

This question is relatively easy to answer with respect to state practice as a generator of CIL. First of all, aside from the Security Council, there are no international institutions authorized to impose binding rules on states. Hence, there is no occasion to ask why practice-generated rules should be allowed to trump institution created rules. Second, the International Law Association's formulation is enlightening. It will be recalled that the International Law Association has provided the following working definition of customary international law:

(i) Subject to the Sections which follow, a rule of customary international law is one which is created and sustained by the constant and uniform practice of States and other subjects of international law in or impinging upon their international legal relations, in circumstances which give rise to a legitimate expectation of similar conduct in the future.

(ii) If a sufficiently extensive and representative number of States participate in such a practice in a consistent manner, the resulting rule is one of "general customary international law." Subject to Section 15, such a rule is binding on all States. ${ }^{358}$

This definition offers a plausible basis for attributing legal effect to state practice seen as legally binding, that is, that such practice creates expectations in other states. It also provides a means for determining the legal effect of a given action, that is, by inquiring as to the extent to which the action create a legitimate expectation regarding future state behavior. To be sure, implicit in that definition is the assumption of an unstated, basic principlethat states ought not violate other states' reasonable expectations. As with the rule pacta sunt servanda, one cannot explain the

358 COMM. ON Formation OF CUSTOMARY (GENERAL) INT'L LAW, FinAL REPORT OF THE COMMITTEE: STATEMENT OF PRINCIPLES APPLICABle to THE ForMATION OF GENERAL CUSTOMARY INTERNATIONAL LAW 8 (2000), available at http://www.ila -hq.org/download.cfm/docid/ A709CDEB-92D6-4CFA-A61C4CA30217F376. 
source of the obligation to apply this principle, though one can note that, just as with pacta sunt servanda, the rule is one which presumably seems a clear matter of common sense in most cultures in the world.

When we turn to the non-practice based sources on which the Court has relied, however, there is no equivalent theory. For example, if one asks why any legal effect should be attributed to a General Assembly resolution, one cannot respond that the General Assembly is authorized to create such effects, because that is not true. One can imagine a case in which states intend that votes by their representatives would create legal effects, but there is no evidence that such a case has existed, and there is considerable reason to doubt that states have that intention in most cases. This is not to say that it is impossible to generate a theory justifying the attribution of legal effect to General Assembly resolutions; it is only to say that it is not obvious what that theory would be, and that, in any case, the Court has certainly put forward no such theory to explain its reliance on formally non-binding sources.

\subsubsection{Analytical Technique}

Questions regarding the Court's analytical technique arise from the extent to which it has arguably departed from what could be called "judicial" modes of behavior in its judgments. In a few cases, there is reason to fear that some judges' negative attitudes toward one of the litigants affected the resulting judgment, ${ }^{359}$ but ultimately, these questions are more fundamental than concerns about judicial bias.

In the first place, courts are expected to explain their judgments. Not only do such explanations provide guidance to those subject to the legal regime the Court is addressing, but they

359 See Military and Paramilitary Activities (Nicar. v. U.S.), 1986 I.C.J. 14, 314 15 (June 27) (Schwebel, J., dissenting) (chastising former President of the Court, Elias, of giving an interview to the Associated Press during the pendency of the case in which he criticized the United States); id. at 179-80 (Elias, J., sep. opin.) ("Apart from the slants given to my alleged remarks, I confirm that the gist of what I am supposed to have said is quite correct and I very much regret the use made of it in a Member of the Court's dissenting opinion to a Judgment which still confirms that the United States of America was found wrong by the Court even under a new President, on all the essential points made by Nicaragua against it."); Oil Platforms (Iran v. U.S.), 2003 I.C.J. 161, 325 (Nov. 6) (Simma, J., sep. opin.) (explaining that he has assented to an opinion he largely disagrees with because he approves of the court's actions in clearly delimiting the legal uses of force, which, he implies, is to scold the United States). 
make clear that the Court's determination is based on existing law, not on extraneous factors. Yet, as I have noted at length, the ICJ not infrequently asserts the legal status of certain purported norms without explaining the derivation of those norms, in circumstances where the norm's existence is not obvious. Some writers have suggested that the collegial nature of the Court makes necessary relatively sketchy opinions, in light of the difficulty of obtaining agreement of a majority of judges on a thorough rationale. ${ }^{360}$ This may be an explanation, but it is not an excuse. If the problem arises from the structure of the Court, then the implication is that the structure of the Court is defective, not that the problem does not exist.

There are a number of examples of the difficulties that can be created by Delphic judicial opinions. For example, as already discussed, the Court in Nicaragua stated that a state's noncompliance with a rule of CIL does not weaken the rule if the state seeks to characterize its behavior as in some way not violating the rule, even, apparently, if the characterization is in bad faith. ${ }^{361}$ This statement implies that the states' descriptions of their practice are as important as the practice itself in determining the content of CIL. This could not be true, however, if the rationale for ascribing law-making effect to state practice is that such practice creates reasonable expectations in other states that future practice will be consistent with current practice, since it would hardly be reasonable for one state to base its expectations regarding the behavior of a second state on descriptions the first state knew to be false. Therefore, the Court must be assuming that there is some basis other than reasonable expectations for seeing practice as capable of creating law. However, the Court never explains what this basis is. Therefore, someone attempting to apply the Court's theory to determine the content of CIL would be unable to do so, since there is no way to know the content of the theory.

Even more troubling is the failure of the Court, in some cases, to acknowledge arguments, or elements of arguments, made by the litigants. Among the principles of procedural fairness that seems universal is the idea that each litigant deserves a hearing-not simply an opportunity to present a case, but a right to have the

360 See, e.g., RoSENNE, supra note 11, at 1545-46 (“[G]iven that a judgment is composed so as to reflect the common opinion of a majority of the judges, economy of expression in the collective collegiate pronouncement is inevitable.").

361 Military and Paramilitary Activities, 1986 I.C.J. at 98. 
decision-maker listen to the case as made. A corollary is that, if the decision-maker rules against a litigant, it is because the decisionmaker has concluded that the litigant's case is without merit and, conversely, that the ruling would have been in the litigant's favor if the decision-maker had determined his argument to be meritorious. If, however, a decision-maker ignores plausible arguments made by a litigant, the decision-maker is failing to explain the flaws in those arguments. Further, such a failure inevitably creates the suspicion that the decision-maker acts as it does because it cannot refute the arguments it ignores but does not choose to admit their correctness, since to do so would require a decision the opposite of that which it wishes to reach. However, a decision that can be supported only by concealing the weakness of the legal arguments against it must derive from some non-legal considerations, not from the law - and a Court that decides cases based on factors other than the law hardly acts as a court of law. Of course, if this conclusion makes sense regarding a court's failure to respond to arguments contrary to its ultimate conclusion, it makes even more sense regarding cases where the court bases its conclusions on a flat misstatement of legally relevant facts.

These defects in the Court's analyses undermine the rationale for judicial resolution of interstate disputes. After all, the rationale for urging states to take their disagreements to courts is the assumption that, if the legal and factual elements of a dispute are considered by an unbiased body whose only objective is to identify and apply legal rules, the states affected by any resulting judgments will see themselves as having been treated justly and therefore be impelled to comply with the judges' resolution of the problem. Of course, there is obvious reason to wonder whether states want a just, as opposed to a favorable, outcome to a dispute. Even if one assumes that states want no more than justice, however, they are unlikely to see themselves as having been treated justly unless the international court to which they resort makes its reasoning transparent, addresses the arguments presented to it and refrains from misstating facts. If it fails in any of these respects, a losing state must doubt the justice of the treatment it received. And if legal institutions act unjustly while lacking the power to coerce, what sense does it make to rely on such institutions?

\section{CONCLUSION}


This article has sought to demonstrate that the ICJ's approach to dealing with state practice, both as that practice pertains to CIL and as it is relevant to the interpretation of particular treaties, is seriously doubtful. The question now is, what ought to be the response to this situation?

In one sense, governments have already responded-only 65 states accept the compulsory jurisdiction of the Court, ${ }^{362}$ and twothirds of the members of the U.N., including four of the five permanent members of the Security Council do not accept that jurisdiction. This relatively limited willingness to use the Court surely, in part, reflects doubts about the way it functions.

But what about situations in which the case reaches the Court under some other heading of jurisdiction, but the Court reaches a clearly incorrect result due either to reliance on doubtful sources of law or to obvious flaws in its analysis? Reisman has pointed out that, prior to the $20^{\text {th }}$ century, the awards of international arbitral panels which exceeded their jurisdiction could be rejected by the states subject to the award on the grounds of excès de pouvoir, ${ }^{363}$ and has suggested that, in light of what he has characterized as the Court's failure to adhere to the internal control mechanisms intended to limit its exercise of authority, its judgments could be ignored on analogous grounds. ${ }^{364}$

This approach seems difficult to reconcile with Article 59 of the Statute, but may be the least bad alternative. A government's first responsibility is to its people, not to the Court. If compliance with a judgment would impose significant costs on a state and the judgment was flagrantly incorrect, it would seem that compliance with a such a judgment would be difficult to defend-it would amount to the government treating its responsibilities to its population as less important than its undertaking to respect a judgment, the poor quality of which was itself evidence that neither the judgment nor the Court rendering it deserved respect.

The flaws in the Court's methods described in this Article ought to have consequences among commentators as well as among governments. These consequences should take the form of avoiding attributing to the Court more authority than its Statute

362 See International Court of Justice, Report of the International Court of Justice 1 August 2006-31 July 2007, U.N. GAOR, 62nd Sess., Supp. (No. 4) U.N. Doc. A/62/4 (Aug. 1, 2007).

363 REISMAN, supra note 346 , at 11-12.

364 Id. at 41-45. 
accords it or than its performance merits. In books and articles too numerous to mention, commentators describe the Court's view of the law as to a particular subject as "authoritative" or describe a disagreement over the content of the law as "settled" once the Court comes down on one side or the other of the disagreement. Nothing in the Statute purports to invest in the Court the authority to, in effect, determine the content of international law outside the context of a particular case. Nor does the Court's performance justify any assumption that its majorities are knowledgeable enough, judicious enough, or disinterested enough to make it reasonable to base deference to it on the collective wisdom it has shown, whatever its formal authority.

Many involved in international law will object to these suggestions. In some cases this reaction may represent nothing more than support for the Court because of agreement with its results, however doubtful those results may be as matters of law. But it must be acknowledged that there will be disinterested arguments against this position as well. How, it might be asked, can states be brought to respect international law if the principal court applying international law is treated with disrespect? And if the Court's judgments do not settle disputed doctrinal points, how can they be settled?

The response is that states have shown their lack of regard for the Court through their unwillingness to rely on it. A refusal to confront possible reasons for that reaction will not somehow induce states to alter their behavior. Certainly, outside the area of maritime delimitation, it is difficult to identify a subject as to which the Court's decisions appear to have influenced the behavior of states very much. And while there is no denying the inconvenience presented by the lack of means for the international legal system to finally resolve doctrinal controversies, the convenience of having a means to resolve such disagreements does not and cannot somehow create the authority to do so improperly.

Most fundamentally, according the Court more authority than can be reconciled with the language of the Statute and the quality of its performance presents a danger to international law. If there are serious questions about the functioning of a tribunal purporting to apply international law, there is a risk that the problem will be thought to lie, not in the court, but in the body of law in question. Reasons to avoid the Court can thus become reasons to ignore the law. Further, the Court can defend itself in such circumstances only by arguing that its results are correct- 
that is, that the flawed rules the Court has applied really are the law. If that approach is taken, however, it can only strengthen arguments that the law "is a ass" - and the consequences that would follow seem obvious.

The current situation is one in which states pay little attention to the Court, which in turn means that it can have little effect on international law as it plays out in the world beyond the academy. Surely, the world would be better off it there was an international court to which states paid attention, even if the price of that attention was the Court's limiting its role to applying the rules that states have authorized it to apply. 